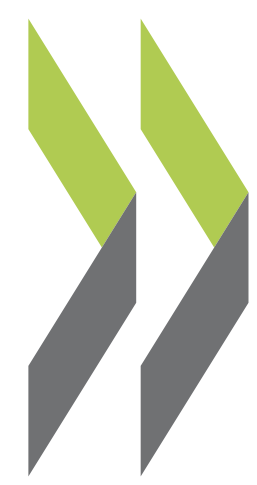

\title{
The potential economic impact of Brexit on Denmark
}

Donal Smith, Mikkel Hermansen, Sune Malthe-Thagaard 
ECONOMICS DEPARTMENT

THE POTENTIAL ECONOMIC IMPACT OF BREXIT ON DENMARK

ECONOMICS DEPARTMENT WORKING PAPERS No. 1544

\section{By Donal Smith, Mikkel Hermansen and Sune Malthe-Thagaard}

OECD Working Papers should not be reported as representing the official views of the OECD or of its member countries. The opinions expressed and arguments employed are those of the author(s).

Authorised for publication by Isabell Koske, Deputy Director, Country Studies Branch, Economics Department.

All Economics Department Working Papers are available at www.oecd.org/eco/workingpapers.

JT03446412 
OECD Working Papers should not be reported as representing the official views of the OECD or of its member countries. The opinions expressed and arguments employed are those of the author(s).

Working Papers describe preliminary results or research in progress by the author(s) and are published to stimulate discussion on a broad range of issues on which the OECD works.

Comments on Working Papers are welcomed, and may be sent to OECD Economics Department, 2 rue André Pascal, 75775 Paris Cedex 16, France, or by e-mail to eco.contact@oecd.org.

All Economics Department Working Papers are available at www.oecd.org/eco/workingpapers.

This document and any map included herein are without prejudice to the status of or sovereignty over any territory, to the delimitation of international frontiers and boundaries and to the name of any territory, city or area.

The statistical data for Israel are supplied by and under the responsibility of the relevant Israeli authorities. The use of such data by the OECD is without prejudice to the status of the Golan Heights, East Jerusalem and Israeli settlements in the West Bank under the terms of international law.

On 25 May 2018, the OECD Council invited Colombia to become a Member. At the time of preparation the deposit of Colombia's instrument of accession to the OECD Convention was pending and therefore Colombia does not appear in the list of OECD Members and is not included in the OECD zone aggregates.

(C) OECD (2019)

You can copy, download or print OECD content for your own use, and you can include excerpts from OECD publications, databases and multimedia products in your own documents, presentations, blogs, websites and teaching materials, provided that suitable acknowledgment of OECD as source and copyright owner is given. All requests for commercial use and translation rights should be submitted to rights@oecd.org 


\section{Abstract / Resumé}

\section{The Potential Economic Impact of Brexit on Denmark}

This paper provides estimates of the potential trade effects on exports and production at the sectoral level as well as GDP in Denmark of the exit of the United Kingdom (UK) from the European Union (EU). Owing to the high uncertainty regarding the final Brexit deal between the EU and the UK, this paper assumes a worst case outcome where trade relations are governed by World Trade Organization (WTO) most favoured nation (MFN) rules. In doing so, it provides something close to an upper bound estimate of the potential negative economic impact. Any trade agreement that would result in a closer relationship between the United Kingdom and the EU than WTO rules reduces the negative impact.

Under the worst case illustrative scenario assumed in this paper, Danish exports to the UK fall by $17 \%$, total exports and GDP decline by $1.3 \%$ in the medium term. This effect is from the trade channel absent any change in foreign direct investment (FDI) or productivity. The fall in exports is concentrated in the Danish agri-food and machinery and equipment sectors, which account for half of the export reduction. Exports to the UK of agri-food and machinery and equipment fall by $24 \%$ and $17 \%$ respectively. Smaller manufacturing sectors such as wood and leather products, metals and textiles see falls of over $20 \%$ in their exports to the UK. The chemicals sector, which includes pharmaceuticals, comprises $9.5 \%$ of Danish exports to the UK and would experience an $18 \%$ reduction in its exports to the UK.

Seven Danish sectors experience production declines of over $2.5 \%$ in the scenario. The largest decline is in the meat products sectors $(7 \%)$, metals $(3 \%)$, material manufacturing $(2.3 \%)$ and other agri-food sectors $(2.2 \%)$. These sectors would also see the largest declines in labour demand.

JEL codes: C68, C10, B17, F13, F14

Keywords: Denmark, Brexit, international trade, European Union, sectoral economic effects, computable general equilibrium model, METRO model.

This Working Paper relates to the 2019 OECD Economic Survey of Denmark (www.oecd.org/eco/surveys/economic-survey-denmark.htm).

$* * * * * * * * * * * * * * * * * * * * * * * * * * * * * * * * * * * * * * * * * * * * * *$

\section{L'impact potentiel du Brexit sur le Danemark}

Nous présentons dans ce document des estimations des effets commerciaux potentiels de la sortie du Royaume-Uni de l'Union européenne («Brexit») sur les exportations et la production par secteur, ainsi que sur le produit intérieur brut (PIB), au Danemark. Compte tenu de la forte incertitude qui entoure l'accord final sur le Brexit entre l'UE et le RoyaumeUni, nous retenons comme hypothèse dans le présent document un scénario du pire dans lequel les relations commerciales sont régies par le principe de la nation la plus favorisée (NPF) de l'Organisation mondiale du commerce (OMC). Ce faisant, nous obtenons un résultat qui s'apparente à une estimation haute de l'impact économique potentiel négatif du Brexit. Tout accord commercial qui se traduirait par des relations commerciales plus 
étroites que celles correspondant à l'application des règles de l'OMC entre le Royaume-Uni et l'UE atténuerait cet impact négatif.

Dans le scénario du pire sur lequel se fonde le présent document, les exportations du Danemark à destination du Royaume-Uni diminuent de $17 \%$, tandis que ses exportations totales et son PIB reculent de $1.3 \%$ à moyen terme. Ces effets résultent du seul canal des échanges, en l'absence de variation de l'investissement direct étranger (IDE) ou de la productivité. La baisse des exportations danoises se concentre dans le secteur de l'agroalimentaire ainsi que dans celui des machines et équipements, qui représentent la moitié de la réduction des exportations. Les exportations de produits agroalimentaires ainsi que de machines et équipements à destination du Royaume-Uni diminuent respectivement de $24 \%$ et $17 \%$. Des secteurs manufacturiers de plus petite taille, tels que ceux du bois, du cuir, des métaux et des textiles, subissent des baisses de plus de $20 \%$ de leurs exportations vers le Royaume-Uni. Le secteur des produits chimiques, qui inclut les produits pharmaceutiques, représente $9.5 \%$ des exportations danoises à destination du Royaume-Uni et voit ses exportations vers ce pays reculer de $18 \%$.

Sept secteurs danois subissent des baisses de production de plus de $2.5 \%$ dans le scénario retenu. Les diminutions les plus marquées sont enregistrées par les secteurs des produits à base de viande $(7 \%)$, des métaux ( $3 \%$ ) et de la fabrication de matériaux $(2.3 \%)$ ainsi que les autres secteurs agroalimentaires $(2.2 \%)$. C'est également dans ces secteurs que la demande de main-d'œuvre recule le plus fortement.

Codes JEL : C68, C10, B17, F13, F14

Mots-clés: Danemark, Brexit, commerce international, Union européenne, effets économiques sectoriels, modèle d'équilibre général calculable, modèle METRO

Ce Document de travail a trait à l'Étude économique de l'OCDE du Danemark 2019 (http://www.oecd.org/fr/eco/etudes/etude-economique-danemark.htm). 


\section{Table of contents}

The Potential Economic Impact of Brexit on Denmark...................................................................... 6

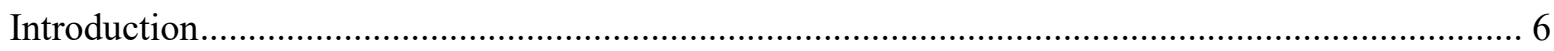

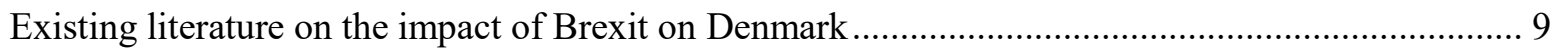

Specification of the illustrative Brexit scenario for Denmark …..................................................... 10

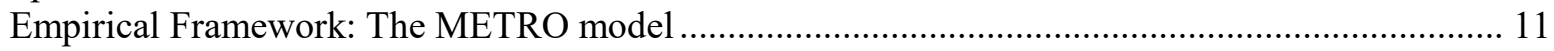

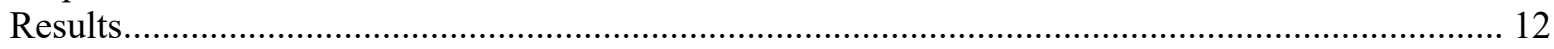

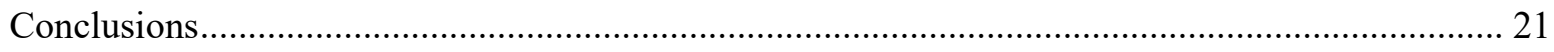

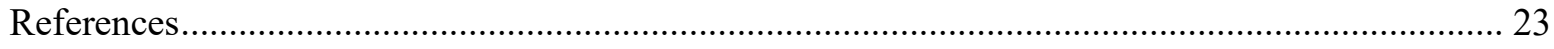

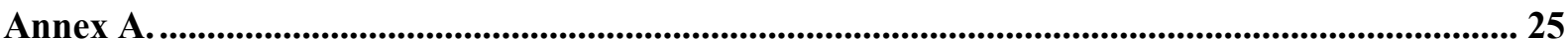

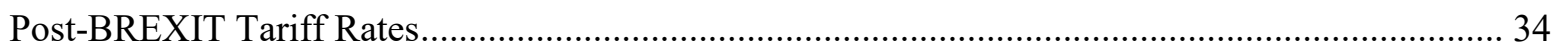

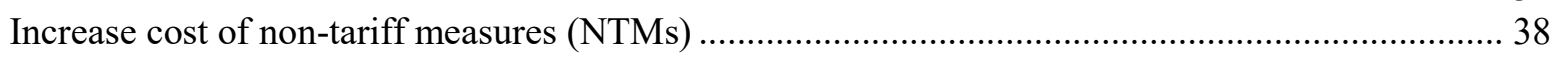

\section{Tables}

Table 1. Previous studies of the impact of a worst-case Brexit on the Danish economy ........................ 9

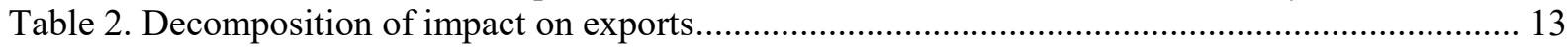

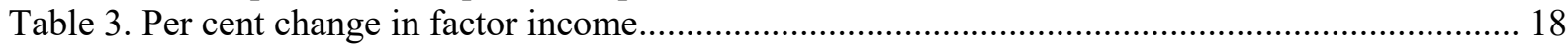

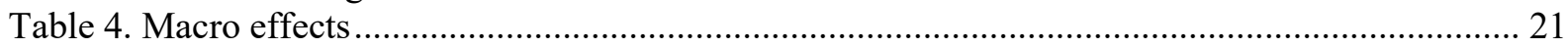

\section{Figures}

Figure 1. Denmark has a close and complex trading relationship with the United Kingdom ................ 7

Figure 2. Per cent change from base of exports to the UK and total exports ..................................... 14

Figure 3. Sector Production shares in Denmark compared to the EU26 average.................................. 16

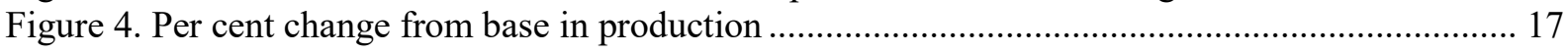

Figure 5. Intermediate inputs: UK per cent of intermediate imports and per cent change in UK

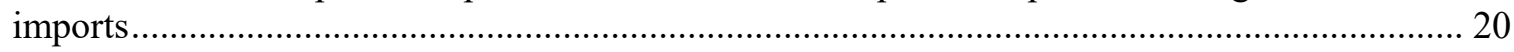




\title{
The Potential Economic Impact of Brexit on Denmark
}

\author{
By Donal Smith, Mikkel Hermansen and Sune Malthe-Thagaard ${ }^{1}$
}

\section{Introduction}

The United Kingdom's planned departure from the European Union (Brexit) could have major economic consequences for Denmark, given the strong bilateral trade and investment linkages between the two countries. The economic impact is transmitted primarily via the trade channel and will impact the sectors of the economy of Denmark to different degrees. The diversity of this sectoral impact will depend on tariff rates and non-tariff measures (NTMs) applied to different products, different UK trade exposures, different degrees of global value chain integration of various sectors, and differences in sectors trade diversion opportunities that may arise as other countries trade flows with the United Kingdom change.

In order to assess the potential trade impact on the Danish economy, an illustrative scenario is simulated using the OECD METRO model (OECD, 2015). METRO is a compatible general equilibrium (CGE) model. The key advantage of METRO for this analysis is that it provides detailed estimates at the product and sectoral level. This provides a single framework to take account of the wide variety of factors that will determine the trade impact, both at the aggregate and sectoral level.

Quantifying the trade exposure to the UK across Danish sectors (Figure 1) shows substantial diversity, which emphasises the importance of a detailed sectoral analysis. Three sectors; agri-food, machinery and equipment and energy and natural resources account alone for $58 \%$ of Danish exports to the UK. The UK in turn accounts for at least $8 \%$ of the total export market of these sectors. As $23 \%$ of total Danish exports to the UK is agri-food products, this sector is the most important in Denmark-UK trade relations. At the same time, the agri-food sector has a comparatively high UK exposure as the UK market buys $11 \%$ of total agri-food exports. Also, the metals sector has a relatively high reliance on the UK market, which accounts for $14 \%$ of the sector's total exports. ${ }^{2}$ Thus, it is the UK exposed sectors of agri-food, machinery and equipment, metals and energy and natural

1 Donal Smith is a junior economist in the OECD Trade and Agriculture Directorate. Mikkel Hermansen is an economist in the OECD Economics Department. Sune Malthe-Thagaard is an economist at Danmarks Nationalbank and was seconded to the OECD Economics Department when the paper was prepared. The authors would like to thank Christine Arriola, Susan Stone and Frank van Tongeren (OECD Trade and Agriculture Directorate) as well as Robert Ford, David Haugh, Patrick Lenain, Alvaro Pereira and Douglas Sutherland (OECD Economics Department) for valuable comments and suggestions. Editorial assistance from Stephanie Henry was also greatly appreciated.

${ }^{2}$ From Table A.1 this sector includes ferrous metals, metals nec and metal products. 
resources that would be expected to be particularly negatively affected by the increase in trade costs. In the results presented in this paper, the sectors presented in Figure 1, are further disaggregated to reveal considerable variability in trade exposure and production effects even within these broad sectors. The broad sectors and their disaggregated subsectors are listed in Table A.1 (Annex).

Figure 1. Denmark has a close and complex trading relationship with the United Kingdom

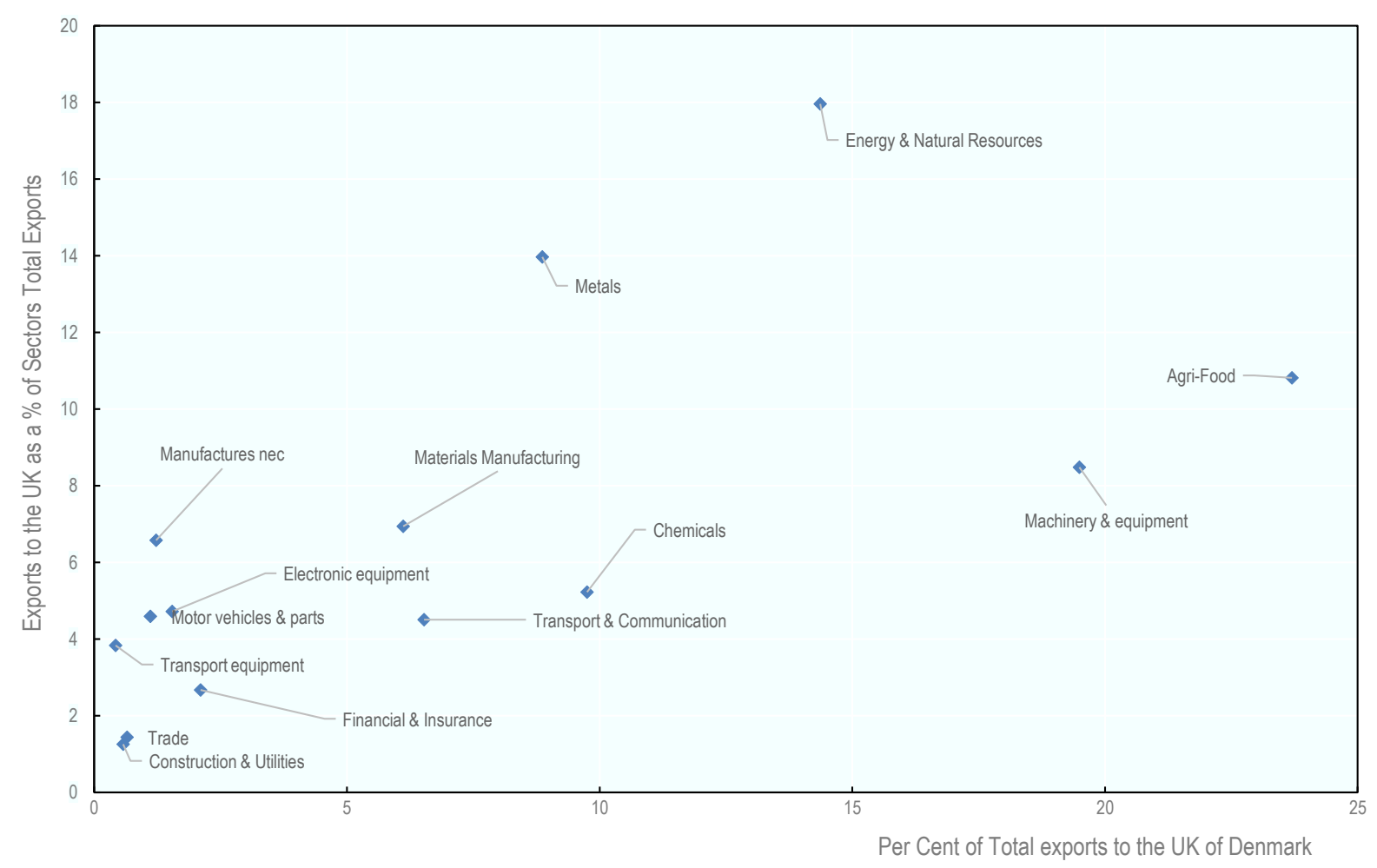

Source: GTAP database, 2011 data as used in the METRO model.

Since the rules governing the future economic relationship between the United Kingdom and the European Union are highly uncertain, a scenario frequently used in empirical work relating to Brexit is to assume Most-Favoured Nation (MFN) standards (e.g. Kierzenkowski et al., 2016; Bergin et al., 2017; Dhingra et al., 2016; Bellora et al., 2017; Vandenbussche et al., 2017). This supposes that trade relations between the EU and UK default to the World Trade Organisation's (WTO) MFN rules, which are the basic rates applied to any WTO member. Relative to current arrangements, this corresponds to an increase in tariff and non-tariff barriers on Danish trade with the United Kingdom. Simulations in this paper are based on this scenario, which could be the result of a disorderly conclusion to negotiations and can be considered as close to a worst case outcome. The scenario is principally chosen because it is associated with an existing tariff schedule and hence reduces the degree of judgment needed to formulate the scenario. Consequently, the results give an upper bound estimate of the size of the negative economic effects on Denmark without representing a judgment about the most likely outcome of Brexit negotiations. In this paper the scenario is applied to the EU as a whole and so the 
impact on Denmark is as a result of both a bilateral change in the trade relationship between Denmark and the UK and also the broader change between the EU and the UK.

This paper contributes to the literature on the impact of Brexit on Denmark as it provides trade and production estimates at a much more detailed level using a CGE approach, allowing the considerable variation within sectors to be analysed. A further contribution is the estimation of the impact of the WTO scenario on factor demands. This allows changes in employment by skill category to be shown at the sector level. The METRO model incorporates OECD Trade in Value Added Data (TiVA) and therefore also allows the analysis of the impact on the participation of sectors in global value chains . In TiVA, imports are disaggregated by end use category, so imports for intermediate use can be specifically modelled. This is of particular importance in the case of Brexit given the depth of integration of the European single market (Rojas-Romogosa, 2016).

This paper has the advantage that the tariff and NTM profile that is imposed in the WTO scenario is specific to Denmark. This is an improvement on some approaches in the existing literature on the impact of Brexit on Denmark as country specific tariff and NTM profiles can differ substantially from an aggregate EU wide profile (Arriola et al., 2018).

Utilising the METRO model has a particular advantage in the modelling of Brexit as it is a detailed general equilibrium model that allows the simulation of complex trade policy scenarios that may not have a historical precedent. A further important aspect is that METRO takes into account potentially important trade diversion effects between countries when both market access to and competition from the UK is hampered.

On the basis of the illustrative scenario the main findings are:

- Danish exports to the UK fall by $17 \%$, total exports and GDP contract by $1.3 \%$ in the medium term, relative to the base scenario. Sectors with a high exposure to the UK, and whose products would face a comparatively large increase in trade costs, are the most severely affected. The fall in Danish exports is thus concentrated in the agri-food and machinery and equipment sectors. These sectors account for $51 \%$ of the fall in Danish exports. Danish exports to the UK of agri-food and machinery and equipment fall by $24 \%$ and $17 \%$, respectively. The agri-food contraction is driven by a substantial $32 \%$ and $21 \%$ decline in exports in the meat products and processed foods sub-sectors, respectively. The agri-food, and machinery and equipment, sectors represent comparatively large shares of the Danish economy compared to the European average, and a significant share of their exports rely on the UK market.

- A number of smaller materials manufacturing sub-sectors and the metals sector also experience large declines in exports to the UK (above 20\%). The Danish chemicals sector, which accounts for $4 \%$ of total production and $9.5 \%$ of total exports to the UK, would experience an $18 \%$ reduction in exports to the UK.

- Seven Danish sectors would experience production declines of above $2.5 \%$ in this simulation. The largest decline is $7 \%$ in the meat products sector, with other large declines in metals, material manufacturing and other agri-food sectors.

- The strongly affected agri-food and machinery and equipment sectors have a relatively high share of workers in the lower skilled category. As a result, lower skilled workers in these industries would experience the largest absolute falls in employment, which could exacerbate short-run costs, as low-skilled workers tend to have more difficulties finding new jobs. Along with declines in labour demand, 
the agri-food contraction would also reduce value of agricultural land by $11 \%$ in the scenario.

- The scenario results in disruption of supply chains for the sectors in Denmark, resulting in an $18 \%$ fall in the imports of intermediate goods from the UK. This decline is more marked in the services side of the Danish economy with the business services and financial and insurance sectors experiencing large declines.

The remainder of this paper is structured as follows. Section 2 discusses previous analyses of the potential impact of the exit of the UK from the EU on the Danish economy. Section 3 specifies the scenario used in the analysis. Section 4 provides a description of the METRO model. Section 5 presents the results and Section 6 concludes.

\section{Existing literature on the impact of Brexit on Denmark}

A few national studies have analysed the impact of Brexit on the Danish economy (Table 1). The Danish Ministry of Finance (2016) found a short-term effect on the level of GDP of around $1 / 2$ percentage point compared to a baseline scenario. The assessment applies export growth estimates from previous OECD work (Kierzenkowski et al., 2016) and assumptions of higher uncertainty, tighter credit conditions and wealth losses from the stock market incorporated in the Danish macroeconomic forecast model (Annual Danish Aggregate Model, ADAM).

Table 1. Previous studies of the impact of a worst-case Brexit on the Danish economy

\begin{tabular}{|c|c|c|c|c|c|}
\hline \multirow[b]{2}{*}{ Study } & \multirow[b]{2}{*}{ Horizon } & \multirow[b]{2}{*}{ Model and channels } & \multicolumn{3}{|c|}{ Estimated effect on } \\
\hline & & & $\begin{array}{l}\text { Exports to } \\
\text { the UK }\end{array}$ & $\begin{array}{c}\text { Total } \\
\text { exports }\end{array}$ & GDP \\
\hline $\begin{array}{l}\text { Danish Ministry of } \\
\text { Finance (2016) }\end{array}$ & $\begin{array}{l}\text { Short-term } \\
\text { (1-2 years) }\end{array}$ & $\begin{array}{l}\text { Macro econometric model: } \\
\text { Trade, capital markets }\end{array}$ & - & - & $-1 / 2 \%$ \\
\hline KRAKA (2017) & $\begin{array}{l}\text { Medium-term } \\
\text { (by 2027) }\end{array}$ & $\begin{array}{l}\text { Macro econometric model: } \\
\text { Trade, capital markets, migration }\end{array}$ & - & - & $-0.20 \%$ \\
\hline $\begin{array}{l}\text { Copenhagen } \\
\text { Economics (2017) }\end{array}$ & $\begin{array}{l}\text { Long-term } \\
\text { (by 2030) }\end{array}$ & CGE model: Trade & $\begin{array}{r}-10.6 \% \text { to } \\
-34.9 \%\end{array}$ & $\begin{array}{r}-1 \text { to } \\
-4.3 \%\end{array}$ & $\begin{array}{r}-0.2 \% \text { to } \\
-1.2 \%\end{array}$ \\
\hline IMF (2018) & Long-term & $\begin{array}{l}\text { CGE model: Trade, capital } \\
\text { markets, migration }\end{array}$ & - & - & $-1 \%$ \\
\hline
\end{tabular}

Source: Ministry of Finance (2016); Hauch et al. (2017); Thelle et al. (2017); IMF (2018).

The private think tank KRAKA analysed the medium-term GDP effects of a hard Brexit (WTO like terms) (Hauch et al., 2017). They assume that Danish trade with the United Kingdom decreases $22 \%$, which is equivalent to a $2 \%$ reduction in total demand for Danish exports, based on Ebel and Warren (2016) estimates of the average effect for other countries. Using ADAM, the direct impact is a $0.3 \%$ GDP fall by 2027 . However, they argue that Brexit also will have indirect effects; less capital mobility will harm GDP further, while less competition from British firms in the remaining EU (higher exports) and better access to labour (that before went to the United Kingdom) will partially counter the negative GDP effects. In total, GDP is estimated to fall around $0.15 \%$ in 2027 compared to baseline.

The consultancy firm, Copenhagen Economics, estimates long-term effects using a global CGE model for a number of Brexit scenarios (Thelle et al., 2017):

- European Economic Area deal (best case) 
- An average European Free trade deal (medium case)

- WTO MFN rules (worst case)

In the long run, the decline in GDP compared to baseline ranges from $0.2 \%$ in the EEA scenario to $1.2 \%$ in the WTO scenario. In the latter case, 0.7 percentage points is due to increased product market regulation increasing trade costs for Danish firms while the remaining part is from higher tariffs.

Exports to the United Kingdom are estimated to decrease by between $10.6 \%$ in the best case to $34.9 \%$ in the worst-case scenario. Brexit will also negatively affect Danish trade with other countries due to value chains where Danish products are used as inputs, for example in German exports to the United Kingdom. Countering this, Brexit provides better export opportunities to other countries due to less competition from the United Kingdom. The total effect on Danish exports range from $-0.6 \%$ to $-2.6 \%$ in the long run. Real wages are estimated to fall by $0.2-1.1 \%$ for skilled labour and $0.2-1.8 \%$ for unskilled labour.

The study includes cross sector interaction through buying and selling intermediate products and through labour and capital markets. The decline in exports is estimated to be largest in the food processing industry (ranging from 3.3\% to 19\%) and metallurgical industry (ranging from $1.4 \%$ to $10.2 \%$ ), while exports from the agricultural sector increase between $0.2 \%$ and $2.9 \%$. Overall, the main export effect is concentrated in the non-service sector ( $95 \%$ of the decrease in exports).

The International Monetary Fund (IMF) use a CGE model with firm heterogeneity and monopolistic competition to quantify the effects on individual EU member states of Brexit (IMF, 2018). Trade linkages are taken from the World Input-Output Database (WIOD) for the year 2011. The paper reports two scenarios; a free trade (FTA) scenario and a hard Brexit WTO scenario with estimates for increases in tariff and non-tariff barriers taken from existing literature. Under FTA and WTO scenarios, output in Denmark is estimated to fall by $0.5 \%$ and approximately $1 \%$ respectively in the long term. Denmark is estimated to be the third most affected member state in both scenarios after Ireland and the Netherlands.

\section{Specification of the illustrative Brexit scenario for Denmark}

As in previous OECD analyses (Kierzenkowski et al., 2016), the effect of a UK exit from the EU is simulated before the United Kingdom reaches any new trade agreements. For illustrative purposes, trade relations between the United Kingdom and all of its partners, both EU and non-EU, are assumed to be governed by the World Trade Organisation's (WTO) Most-Favoured Nation rules (MFN). Tariffs on goods exported from the United Kingdom are assumed to increase to the importing country's WTO MFN bound rates once the United Kingdom formally exits the European Union. Contemporaneously, the United Kingdom imposes tariffs, equivalent to EU bound rates, on goods imported into the country.

The post-Brexit tariff rates between the United Kingdom and EU member states in the model are set as the MFN bound tariff rates of the European Union in each sector. Although a strong assumption, it is also assumed that the United Kingdom will apply the EU MFN bound rates on imports from the rest of the world. This post-Brexit rate is operationalised in the model by applying a mark-up on the current bilateral applied rate. The mark-up is the percent increase between the applied and the bound rate of the European Union calculated using the WITS-IDB database. Table A. shows the mark-up applied to the 
bilateral import rates faced by exporters of goods to the United Kingdom. In a similar fashion, a mark-up is applied on tariff rates faced by UK exports to the rest of the world. This mark-up is based on the percent increase between the applied rates on imports from the UK and the MFN bound rates of regions in the WITS-IDB database. Table A.12 shows the mark-up rate applied to a region's current ad valorem tariff rate in the model to simulate the post-Brexit import tariff rates faced by the United Kingdom. In cases where UK imports currently enter duty free, the region's MFN bound rates are applied.

Once the United Kingdom leaves the customs union, any introduction of administrative rules, like customs declarations, possible border checks, and health or technical compliance reviews, could increase the cost of trade with the remaining EU countries. Moreover, over time, regulatory divergence between the United Kingdom and the European Union could add additional costs to exporters from meeting differing requirements to trade and verifying that requirements are met. These assumed costs would occur on both sides of UK-EU trade and are illustrated by imposing new trade costs related to non-tariff measures (NTMs).

The increase in costs is assumed to be $50 \%$ of tariff equivalent estimates of NTMs on goods imported into the EU faced by non-member countries (for more details, see OECD 2018b). The increase is applied as an iceberg cost (trade costs are modelled as an ad valorem tax equivalent but do not result in any additional revenue) for the simulation. The NTM's between the UK and non-EU countries remain unchanged.

Services trade, while not subject to tariffs, is subject to rules, regulations, and other nontariff measures incurring some cost, which could increase post-Brexit. The increased cost of services trade between the United Kingdom and the European Union is also simulated as NTM's. Services NTMs are also computed as $50 \%$ of the increase in tariff equivalents of NTMs. This is equal to the weighted average of the CEPII import restrictiveness index (Fontagné et al., 2016) across all of a country's trading partners. ${ }^{3}$

\section{Empirical Framework: The METRO model}

The METRO model is a CGE model and is described in detail in OECD (2015). For this analysis the model is aggregated to 10 regions, 40 sectors of the economy, and eight types of factors, with the United Kingdom and Denmark disaggregated from the rest of the European Union (EU 26). ${ }^{4}$ The simulations represent medium-term shocks where production factors are mobile, but there is no capital accumulation. As such the time horizon of the estimated effects can be taken as a period that allows adjustment of labour and some reallocation of capital across sectors, but not including longer-term structural effects. This is assumed to be around 5 years.

CGE models rely on a comprehensive specification of all economic activity within and between countries (and therefore the different inter-linkages that tie the countries together) and are suitable for examining the impact of a wide range of different trade shocks. The

\footnotetext{
${ }^{3}$ The model estimates are conservative since it is not assumed that the UK faces changes to NTMs in non-EU countries. Additionally, in case of specific or mixed tariffs which can change from value to volume based tariffs with the amount of trade, we have no corresponding AVE bound rate, or it is unclear how they are treated in the WTO database. This is specifically the case in agriculture and food, as well as steel and chemicals, in some cases. Tariff rate quotas (TRQ), where tariffs can vary with the quantity traded, are another difficult issue. Where the EU has a TRQ access, it cannot automatically be assumed that the UK after Brexit would inherit a share of the quota .

${ }^{4}$ Excluding the United Kingdom and Denmark.
} 
METRO model builds on the GLOBE model developed by McDonald and Thierfelder (2013). The novelty and strength of the METRO model lies in the detailed trade structure and the differentiation of commodities by end use. Specifically, commodities and, thus, trade flows, are distinguished by end-use category; for intermediate use, for use by households, for government consumption, and as investment commodities.

The underlying framework of METRO consists of a series of individually specified economies interlinked through trade relationships. As is common in CGE models, the price system in the model is linearly homogeneous, with a focus on relative, not absolute, price changes. Each region has its own numéraire, typically the consumer price index, and a nominal exchange rate (an exchange rate index of reference regions serves as model numéraire). Prices between regions change relative to the reference region.

The database of the model relies on the GTAP v9 database (Aguiar et al., 2016) in combination with the OECD TiVA data. Policy information combines tariff and tax information from GTAP with OECD estimates of non-tariff measures on goods, trade facilitation and export restricting measures. The dataset contains 61 countries and regional aggregates and 57 commodities.

The model is anchored in microeconomic theory. Firms maximise profits and create output from primary inputs (i.e. land, natural resources, labour and capital), which are combined using constant elasticity of substitution (CES) technology, and intermediate inputs in fixed shares (Leontief technology). Households are assumed to maximise utility subject to a Stone-Geary utility function, which allows for the inclusion of a subsistence level of consumption. All commodity and activity taxes are expressed as ad valorem tax rates, and taxes are the only income source to the government. In this study, the government is assumed to maintain an internal balance by adjusting its expenditure. At the same time, the trade balance is variable, and the nominal exchange rate is flexible in the simulations. ${ }^{5}$ Nominal wages are assumed downwardly rigid, but remuneration rates of all other factors (land, capital, natural resources) are assumed to adjust.

\section{Results}

As METRO is a trade model the results at the detailed sectoral level for exports, production and value chains are presented first followed by macroeconomic estimates. The sectoral results are presented at two levels of aggregation. Firstly, broad aggregate sectors are presented for illustrative purposes to provide an overview of the most exposed and affected sectors. This level of aggregation used is shown in Figure 1 and detailed in Table A.1 (Annex). Secondly, the main results of the METRO simulation for trade, production, factor use and value chain impacts are presented using more disaggregated sectors which are also listed in Table A.1 (Annex). The scenario is applied to the EU as a whole so the impact on Denmark is because of both a bilateral change in the trade relationship between Denmark and the UK, and also the broader change in trade costs between the EU and the UK.

The United Kingdom is an important trading partner, accounting for 7\% of both total Danish exports and imports respectively (Table A.2 and Table A.3, Annex). ${ }^{6}$ As a

\footnotetext{
${ }^{5}$ This is a necessary assumption of the model, with little quantitative implications compared to a fixed exchange scenario. No assumptions are made on a change in the relationship between the Danish Krone and euro in a worst-case Brexit scenario.

${ }^{6}$ Source: GTAP database, 2011 data as used in the METRO model.
} 
consequence, trade is an obvious channel through which the impact of Brexit on the Danish economy would be felt. From the aggregate perspective the METRO model estimates that the increase in tariff and non-tariff costs of exporting into the United Kingdom would result in a decline of $17 \%$ in total Danish exports to the UK from baseline levels (Table 2). While there would be some trade diversion, that is exports to all other markets increase as importers switch from UK to other markets with some gains for Denmark, the increases are not enough to cover the loss in the UK market. As result, total Danish exports decline 1.3\% from base levels.

Table 2. Decomposition of impact on exports

\begin{tabular}{lrrrrrrr}
\hline & \multicolumn{3}{c}{ \% change } & \multicolumn{2}{c}{ \% of total decline } & \multicolumn{3}{c}{ Value at base (USD millions) } \\
\hline Denmark & Total & DNK $\rightarrow$ UK & DNK $\rightarrow$ EU26 & & \multicolumn{1}{c}{ Total } & DNK $\rightarrow$ UK & DNK $\rightarrow$ EU26 \\
\hline Total & -1.3 & -17.4 & -0.1 & 100 & 159,728 & 10,266 & 75,429 \\
Intermediates & -1.2 & -16.7 & 0.1 & 55.3 & 85,411 & 5,895 & 43,890 \\
private consumption & -2 & -19.3 & -0.5 & 36.2 & 41,454 & 3,351 & 22,109 \\
government consumption & -1.3 & -14.9 & -1 & 0.9 & 4,616 & 110 & 1,798 \\
capital goods & -1 & -14.9 & -0.1 & 7.6 & 16,303 & 910 & 7,633 \\
\hline
\end{tabular}

\section{The Danish meat products and machinery sectors are the most reliant on exports to the $U K$}

The agri-food, machinery and equipment, metals, and energy and natural resources are most exposed to the aggregate decline in trade (Figure 1). Looking at the sub-sectors, the meat products (within the agri-food sector) and the oil sub-sectors (within energy and natural resources sector) are more vulnerable to Brexit since exports to United Kingdom account for $20 \%$ and $26 \%$ respectively of total exports in these sectors (Table A.2, Annex).

There are six Danish sub-sectors for which the UK market accounts for at least nine per cent of exports within the sector (Table A.2, Annex). Three of these sub-sectors are in the broad agri-food sector and are meat products, processed foods and horticulture. The oil, metal products and petroleum, coal products sectors are the other sub-sectors with a comparatively high reliance on the UK as an export destination.

Looking at total Danish exports to the UK across all sectors, it is notable that even at the more detailed disaggregation, the sub-sector machinery and equipment nec (not elsewhere classified) stands out as accounting for $19 \%$ of total Danish exports to the UK. This share of total exports to the UK is 8 percentage points above any other sub-sector.

\section{Materials manufacturing and agri-food sectors experience the largest fall in exports to the $U K$}

Different degrees of UK trade exposure, trade cost increases from both tariffs and NTM's and potential for market diversion among the sectors of the Danish economy lead to a diverse sectoral reaction to the scenario (Figure 2). In the METRO scenario the largest absolute falls in exports are in agri-food and machinery and equipment which have relatively more UK exposure than other sectors in Denmark (Figure 1). These two sectors account for $51 \%$ of the total fall in Danish exports in the simulation.

In percentage terms, it is the materials manufacturing sector that experiences the largest fall in exports to the UK with a $28 \%$ decline (Figure 2). The next most affected sectors are agri-food and transport equipment; both of these sectors see a $24 \%$ reduction in their 
exports to the UK. The metals sector sees the largest decline in total exports at $3.6 \%$. This is due to a $21 \%$ fall in exports to the UK.

The energy and natural resources, and chemicals sectors also have comparatively higher UK trade exposures (Figure 1). Chemicals exports to the UK, which includes pharmaceuticals, would fall $18 \%$. This results in an overall fall of $1.1 \%$ in total chemical exports relative to base. This results in the third largest absolute fall in exports to the UK of all the sectors, due to this sectors large share of total Danish exports to the UK. While the energy and natural resources sector has a high exposure to the UK, the availability of other markets through trade diversion means that, while this broad sector's exports to the UK fall by $8 \%$, total exports are reduced by only $0.2 \%$ relative to base levels.

While all sectors would experience a decline of at least $7 \%$ in their exports to the UK, some are able to find alternative markets to partly or fully compensate for the loss of market access. In the financial and insurance, and the motor vehicles and parts sectors exports to the UK are estimated to fall by $8 \%$ and $12 \%$, respectively, in the simulation, however their total exports increase by $0.9 \%$ and $3 \%$. This net increase is due to market diversion effects with both sectors having an increase of above $4 \%$ in exports to other EU markets in the scenario (Table A.4, Annex). By contrast, the economically important sector of machinery and equipment which relies on the UK for $8.5 \%$ of its export market experiences very little market diversion in the scenario, and thus its exports to the UK and total exports would both fall by $17 \%$ and $1.7 \%$ respectively. As will be discusses subsequently this sector accounts for a comparatively large share of Danish output.

Figure 2. Per cent change from base of exports to the UK and total exports

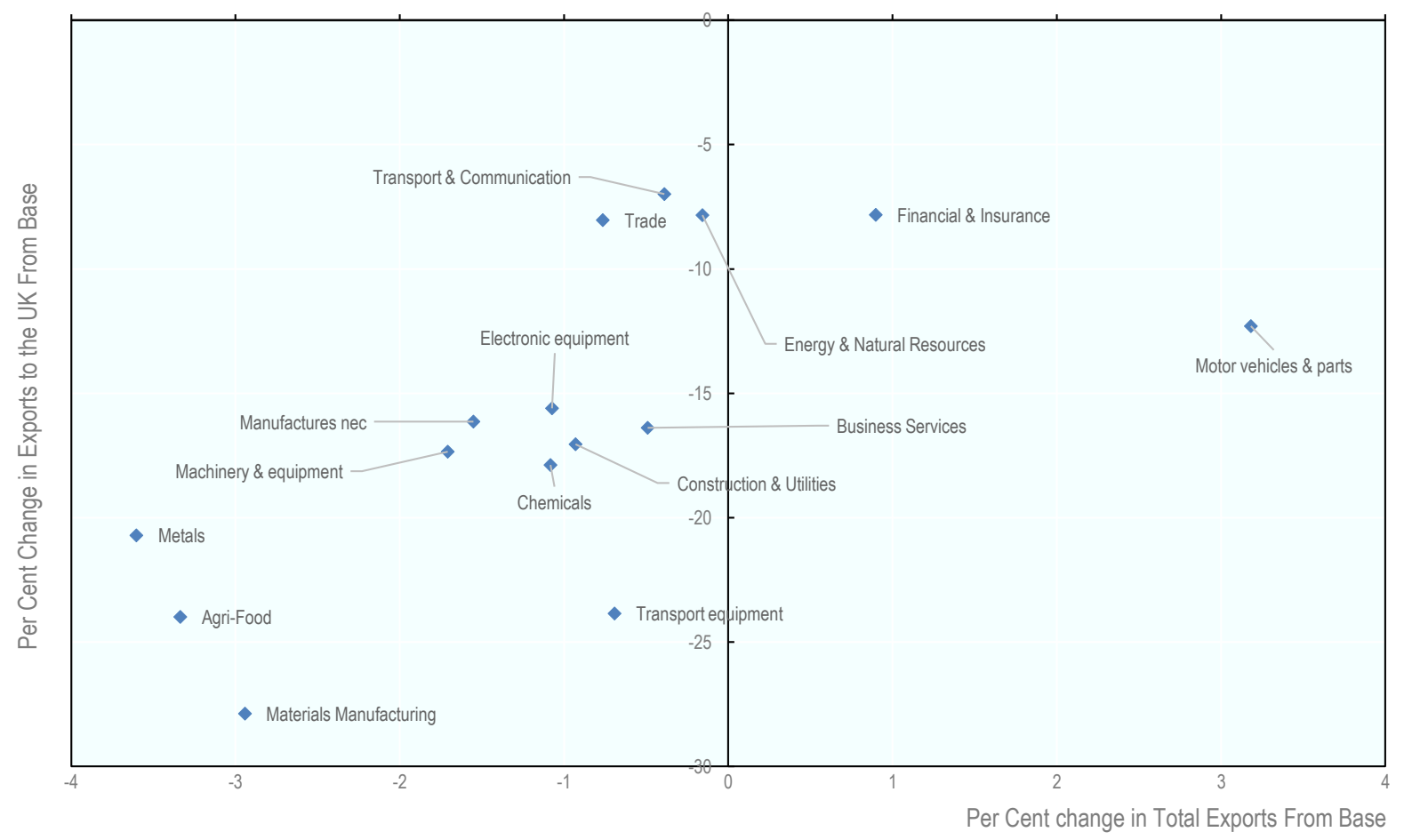

Source: OECD METRO model estimates. 


\section{Reductions in meat products and machinery and equipment account for a large share of the export decline}

At the more disaggregated sub-sector level the export decline shown in Figure 1 is heavily concentrated. In absolute terms, $38 \%$ of the decline in total Danish exports to the UK is in two sub-sectors: meat products; and machinery and equipment. The more detailed level of sectoral analysis reveals that within the agri-food sector the export decline result is driven by reductions in the exports to the UK of both the meat products and processed foods subsectors (Table A.4, Annex). These sectors' exports to the UK fall by $32 \%$ and $21 \%$ respectively and their total exports are reduced $8 \%$ and $3.6 \%$, respectively. The meat products sub-sector is very exposed to Brexit, with the UK accounting for $20 \%$ of the sector's exports.

The wearing apparel component of the materials manufacturing sector would have the largest decline in exports to the UK of $40 \%$. There are also large declines for the other subsectors within materials manufacturing, including falls in the exports to the UK of textiles, leather products and wood products above $21 \%$. The metals and metal products nec subsectors would see declines in exports to the UK of $22 \%$ and $19 \%$ respectively. In total, at the 39 sub-sector level, nine Danish sub-sectors would experience a fall in exports to the UK of above $20 \%$ and six see declines in total exports of above $3 \%$ in the simulation (Table A.4, Annex).

The importance of the market diversion effects in mitigating the total impact in the scenario for the relatively more UK exposed energy and natural resources sector is also observable at the more detailed level of aggregation. The petroleum, oil and gas sub-sectors would all have increases in their exports to the rest of the EU (Table A.4, Annex). In the case of the gas sub-sector, the increase in exports to the EU would be $8 \%$ above the base. Positive effects can occur as the scenario causes price changes across a range of goods. If these are intermediate inputs, for example, it can increase the price competiveness of that sector's exports.

\section{Denmark has a comparatively large machinery and equipment sector}

Of Denmark's traded sectors, in absolute terms, the largest sector in the Danish economy is business services, accounting for $14 \%$ of Danish output. This is similar to many advanced economies, where services have a large share of GDP. ${ }^{7}$ However, Denmark has higher shares of production ${ }^{8}$ than the EU 26 in the machinery and equipment, agri-food, transport and communications and financial and insurance service sectors (Figure 3).

\footnotetext{
${ }^{7}$ Source OECD METRO model data.

${ }^{8}$ Production is comprised of both intermediate input use and domestic value added.
} 
Figure 3. Sector Production shares in Denmark compared to the EU26 average

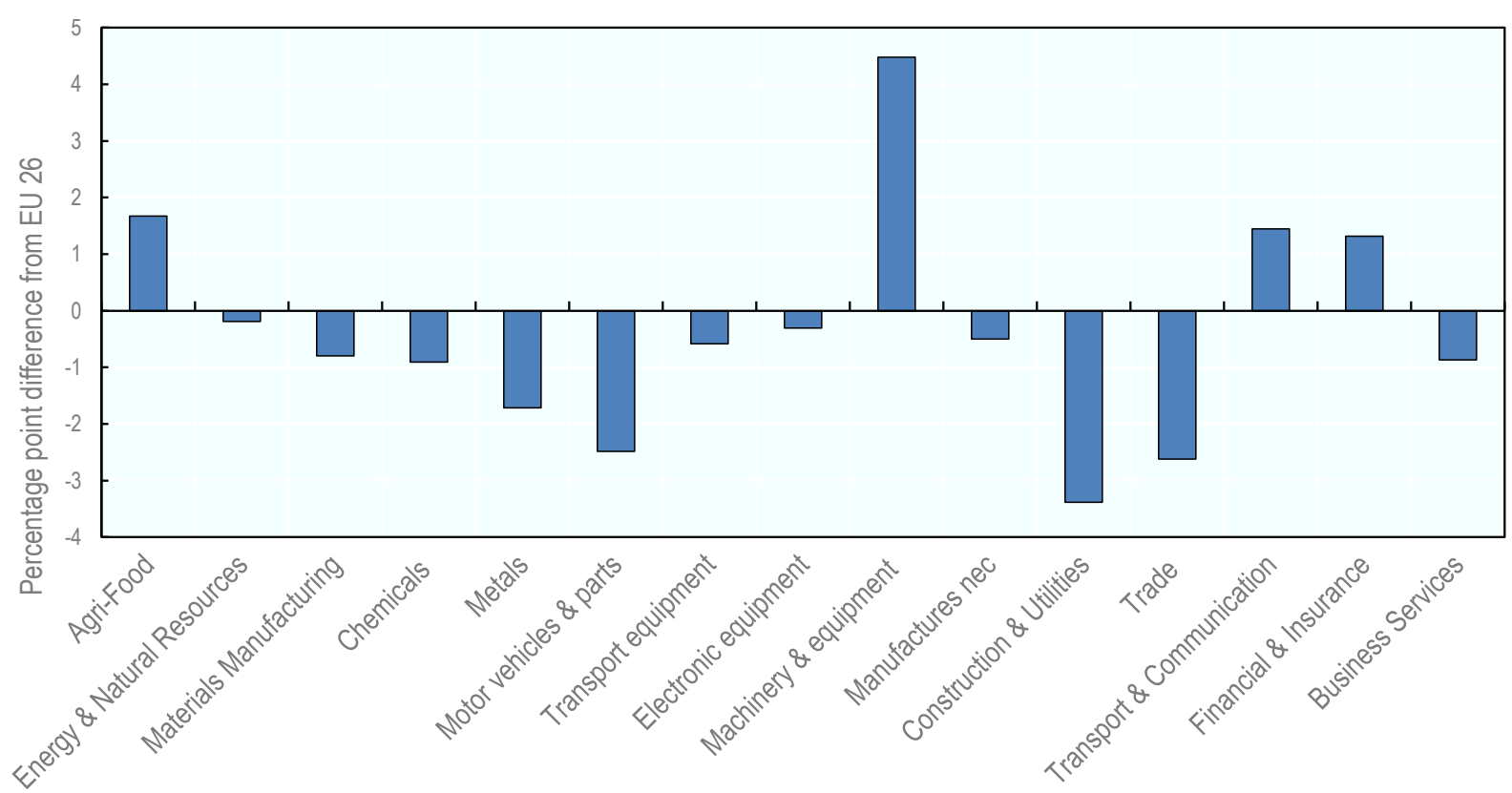

Note: The machinery and equipment sector accounts for $10 \%$ of total output in Denmark, while the average share in EU26 is 5.5\% (the bar shows the 4.5 percentage point difference). Agri-food accounts for $7.7 \%$ of total Danish production, 1.7 percentage point above the EU26 average of $6 \%$.

Source: Source OECD METRO model data.

\section{The agri-food and materials manufacturing sector experience the largest falls in production}

The scenario results show that the impact on output of these sectors from reduced access to UK market ranges from reduction to gains in some sectors (Figure 4). ${ }^{9}$ In the scenario seven sub-sectors would experience declines in production of more than $2.5 \%$ (Table A.6, Annex). As expected, three of these are in the agri-food sector, with the largest production decline in meat products of $7 \%$. Processed food and agriculture decline by $3 \%$ and $2.8 \%$ respectively in the simulation. These production falls in the Danish agri-food sector are well above the average reduction in these sectors in the EU 26. As noted Denmark also has a comparatively large machinery and equipment sub-sector and production in this sector falls by $1.4 \%$ in the scenario. Given its large share of the economy, this fall has an overall impact on output that is more than double of more strongly impacted but smaller processed foods sub-sector.

Although small in terms of output in the overall Danish economy, large percentage falls occur in the materials manufacturing sub-sectors, with wearing apparel, textiles and wood products experiencing the largest declines. This is similar to the case of Ireland, where some smaller manufacturing sectors were among the most negatively affected sectors in a WTO scenario (Arriola et al., 2018). This is due to these products having a comparatively high share of exports to the UK, lacking trade diversion opportunities and also facing comparatively higher tariff and NTM's in the scenario. The metal products sub-sector would also have a comparatively large decline in production of $3.3 \%$. This is due to the

\footnotetext{
${ }^{9}$ This table presents the aggregated sectors as detailed in Figure 1 and Table A.1.
} 
importance of the UK as an export market for this sector at 20\% of total exports (Table A.2, Annex). The relatively UK exposed chemicals sub-sector has a $1.1 \%$ fall in production due to the $18 \%$ decline in exports to the UK.

The exports of other large Danish sectors such as business services, trade and transport, are not as strongly impacted by the scenario and so their production declines are on a smaller scale. The financial and insurance and motor vehicles and parts sectors would experience an increase in production in the scenario. This is due to the strong trade diversion effects, with both sectors having an increase in their exports to the EU 26 (Table A.4, Annex).

Figure 4. Per cent change from base in production

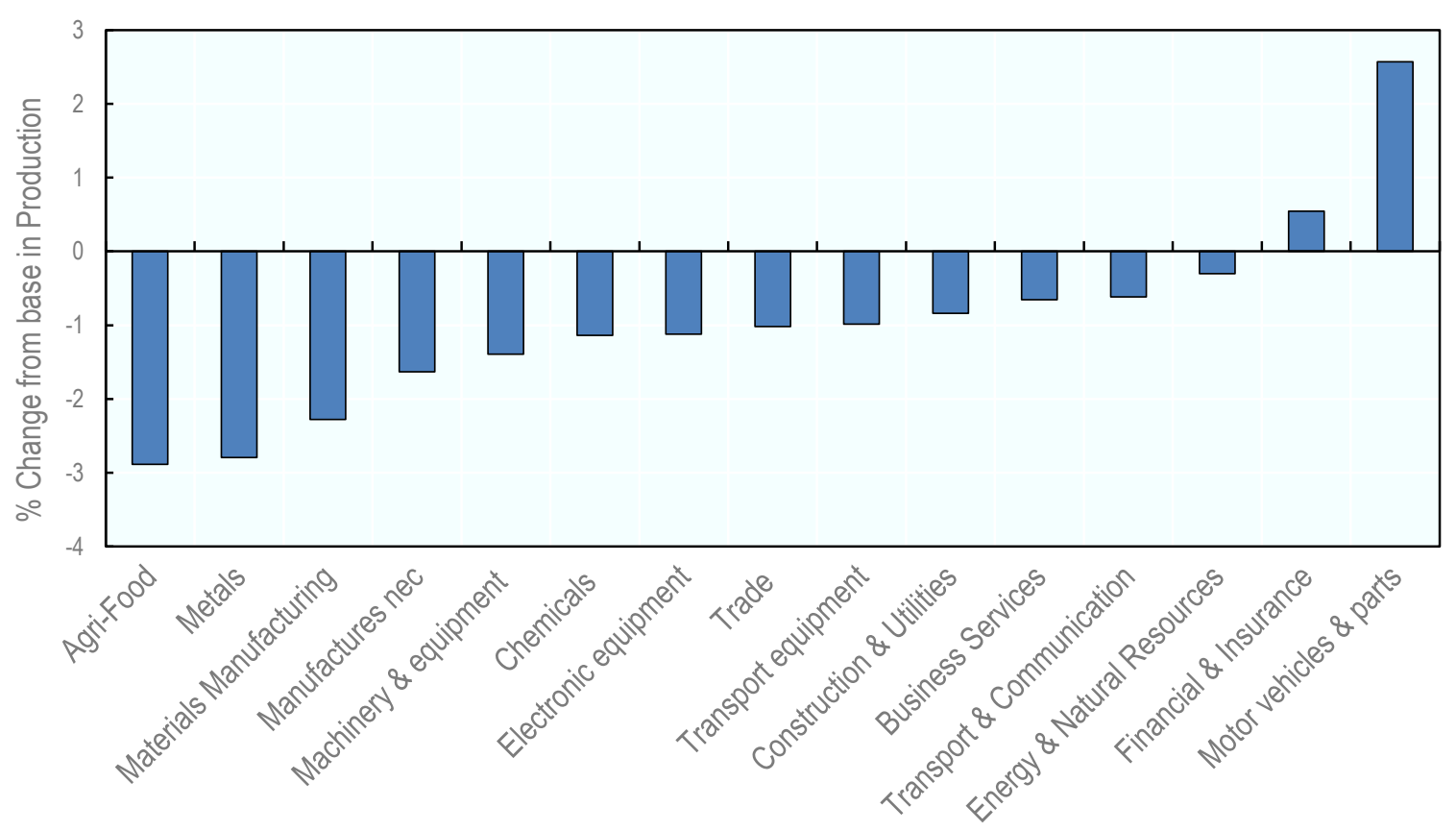

Source: GTAP database, 2011 data as used in the METRO model.

\section{Brexit leads to a reduction in employment in the comparatively low skilled agri- food and machinery and equipment sectors}

The METRO model captures the impact on the supply and demand for each production factor: land; labour; and capital (Table 3). The trade disruption caused by Brexit leads to production declines across industries and thus declines in factor demand. The production impact across the agri-food sector is reflected in the declines in factor income. There is a $10.6 \%$ fall in the value of agricultural land, a factor of production used exclusively by the agri-food sectors (Table A.9, Annex). This is notable as Denmark has the highest share of its total land area devoted to arable land and permanent crops of all OECD countries at $55 \%$. If pasture land and meadows are included Denmark's share is the third highest, behind that of the UK and Ireland. The decline in the value of agricultural land in the scenario is substantial; it is close to triple the average land value decline in the rest of the EU. This further highlights the relatively high trade exposure of the agri-food sector in Denmark to Brexit compared to other Danish sectors as they are the sole users of this resource. 
Table 3. Per cent change in factor income

\begin{tabular}{lcccccrr}
\hline & Land & $\begin{array}{c}\text { Technical and } \\
\text { Assistant } \\
\text { Professionals }\end{array}$ & Clerks & $\begin{array}{c}\text { Service and } \\
\text { shop } \\
\text { assistants }\end{array}$ & $\begin{array}{c}\text { Office managers } \\
\text { and Professionals }\end{array}$ & $\begin{array}{c}\text { Agricultural and } \\
\text { other low skilled } \\
\text { workers }\end{array}$ & $\begin{array}{c}\text { Capital } \\
\text { Resources }\end{array}$ \\
\hline Denmark & -10.6 & -1.8 & -1.2 & -1.7 & -1.8 & -1.7 & -0.6 \\
European & -3.6 & -1.3 & -0.8 & -1.0 & -1.4 & -0.9 & -0.4 \\
Union 26 & & & & & -0.6 & \\
\hline
\end{tabular}

In terms of labour, factor demand can be thought of as the overall wage bill (number of workers times wages). In the model nominal wages are assumed to be downwardly rigid and so changes in labour factor incomes reflect changes in employment. The declines in each category of worker are from 1.2 to $1.8 \%$, with office managers and professionals having the largest reductions (Table 3 ). In the model this category makes up the majority of workers in Denmark at $26 \%$ of the labour force (Table A.7, Annex). The overall reduction in the labour force is $1.7 \%$.

\section{Employment falls strongest among low-skilled workers in the agri-food sectors}

At the sectoral level the declines in labour demand match the production declines with a $7.4 \%$ fall in demand for labour in the meat products sub-sector and more than a $3 \%$ decline in processed foods and agriculture (Table A.8, Annex). This fall in the meat products is the largest of all the sub-sectors. Again matching production, seven of the eight sub-sectors that record the largest declines in employment are in either agri-food or materials manufacturing. In the comparatively large machinery and equipment sub-sector labour demand would decline by $1.7 \%$.

The impact on employment could be particularly painful since the most affected sectors employ many low-skilled workers and the agri-food sector is concentrated outside the larger cities and especially in the western part of the country. Finding new employment for these workers could thus be difficult in a worse-case scenario. Nevertheless, the flexible Danish labour market and strong policies for reskilling of job seekers provide a strong basis to facilitate the needed reallocation of workers across sectors.

In the meat products sub-sector the absolute fall in employment is the largest among agricultural and other low skilled workers. This category of workers accounts for $39 \%$ of labour in the sector and their employment would fall 7.4\% (Table A.9, Annex). Agricultural and other low skilled workers have a higher concentration in the agri-food sector relative to other sectors. These workers account for $66 \%$ of employment in this sector compared to an average of $19 \%$ across the whole Danish economy.

In the important machinery and equipment sector, employment among technical and assistant professionals experience the largest effect by a $1.9 \%$ decline. However, in absolute terms, employment of low-skilled workers (agricultural and other low skilled workers) declines the most since this group compose $39 \%$ of total employment in the machinery and equipment sector.

Overall, services account for the largest absolute decline in labour demand since services make up more than three-fourths of the Danish economy. Financial services and insurance stands out with a small employment gain in this worst-case scenario. In this sector, lowskilled employment make up only $1.3 \%$ of employment, while $46 \%$ are technical and assistant professionals.

Initial factor demands show the relative capital and labour intensities in each sector (Table A.9, Annex). These figures show that smaller metals sectors are, along with 
construction, the most labour intensive sectors in the Danish economy. In terms of capital input the meat products sub-sector has the largest decline in capital with a $6 \%$ fall. ${ }^{10}$ This sector does, however, only account for a small fraction of the total capital stock in the Danish economy. Business services have the largest share at $20 \%$. In the scenario, this sector expands its capital by $0.3 \%$.

\section{Brexit impairs the participation of Denmark in global value chains}

In addition to gross trade flows, the participation of Denmark in global value chains (GVC's) and how that participation changes as a result of the Brexit can be examined. This is an important consideration as participation in GVC's allows higher levels of specialisation, productivity growth and thus job creation (OECD, 2017).

Different sectors in Denmark have different levels of usage of intermediate inputs in production. Of the total value of production in both the Danish agri-food and transport equipment sectors, $72 \%$ is accounted for by intermediate inputs, both imported and domestically sourced, with the remainder being domestic value added. These are the highest percentages of any sector; the lowest is in financial and insurance at $43 \%{ }^{11}$

In the scenario, with restricted access to the UK market, the sourcing of intermediate inputs from the UK falls in all sectors. The largest fall in intermediate imports from the UK is estimated to be in the motor vehicles sector, with a 59\% reduction from the base (Figure 5). The second largest fall in imports of $40 \%$ would be in the financial and insurance sector. This loss is concentrated in the financial services sub-sector, which would experiences a $45 \%$ drop in imports of intermediates of $45 \%$, whereas the insurance sub-sector would have only a $5 \%$ fall. Although the fall would be larger for the motor vehicles sector, UK intermediates imports are more important for the financial and insurance sector, accounting for $14 \%$ of total imported intermediates, as compared to $0.5 \%$ in motor vehicles. In both the exposed agri-food and machinery and equipment sectors the fall in intermediate sourcing from the UK is $16 \%$. The total reduction in intermediate imports from the UK would be $18 \%$. This is an indication that the connection of the sectors of the Danish economy to supply chains is disrupted.

\footnotetext{
${ }^{10}$ In the model there is no capital accumulation and so changes in capital represent a reallocation across sectors.

${ }^{11}$ Source: OECD METRO model data.
} 
Figure 5. Intermediate inputs: UK per cent of intermediate imports and per cent change in UK imports

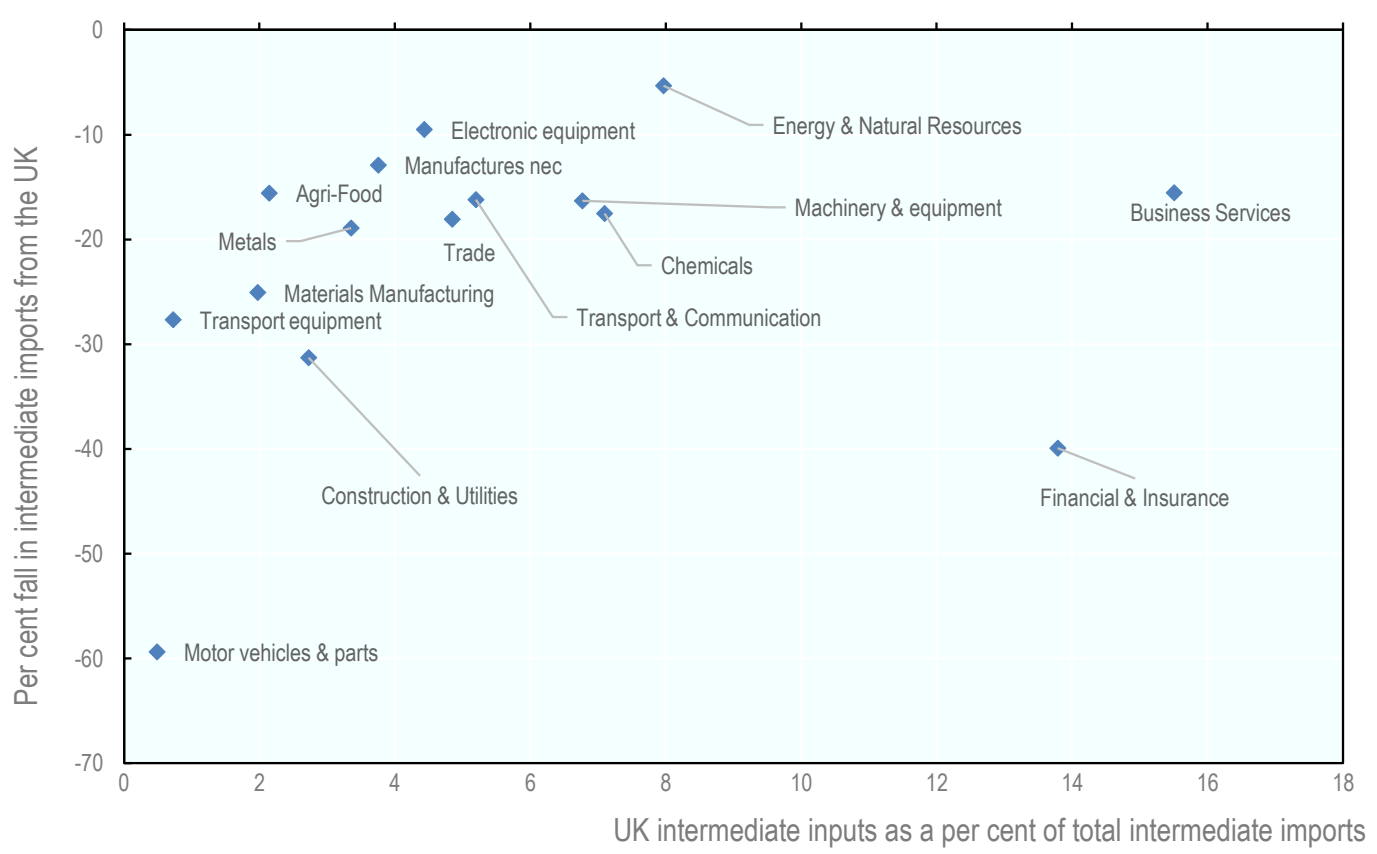

Source: OECD METRO model estimates.

\section{At the macroeconomic level the trade reliant Danish economy is relatively more exposed to Brexit}

Due to the strong trade and financial linkages between Denmark and the UK the scenario would have sizable macroeconomic consequences for Denmark (Table 4). The macroeconomic effects presented come from the trade channel. Other channels not captured in the model that may influence the macroeconomic outcome include the relocation of FDI and productivity effects. ${ }^{12}$ In the base data of the METRO model the UK accounts for $14 \%$ of EU real GDP and $10 \%$ of EU export demand, a trade disruption between the UK and EU economies can thus potentially have a strong impact on other member states.

\footnotetext{
${ }^{12}$ See Paczos (2018) for a discussion of channels captured by different trade modelling approaches.
} 
Table 4. Macro effects

$\%$ change from baseline

\begin{tabular}{ccc}
\hline & Denmark & European Union \\
\hline Real GDP (expenditure) & -1.3 & -0.7 \\
Final Domestic Demand & -1.3 & -0.8 \\
Private consumption & -0.8 & -0.5 \\
Government consumption & -2.0 & -1.5 \\
Investment consumption & -1.3 & -0.8 \\
Import demand & -1.3 & -0.8 \\
Export demand & -1.3 & -0.8 \\
Domestic production & -1.2 & -0.7 \\
Intermediate use & -1.3 & -0.7 \\
\hline
\end{tabular}

For the analyses, we simulate the effects transmitted to Denmark through the trade channel. Denmark is more exposed to a trade shock relative to other member states as exports account for $55 \%$ of Danish GDP, compared to the EU average of $39 \%$ in 2017 . The UK, accounting for $7 \%$ of Denmark's total exports. Over the medium-term Danish real exports fall by $1.3 \%$ relative to the base, reducing demand in Denmark. The fall in exports results in a medium-term $1.3 \%$ reduction in real GDP relative to the base. It is notable that, even accounting for additional complex dynamics, such as firm heterogeneity and monopolistic competition, the IMF estimate for a GDP fall for Denmark of approximately $1 \%$ is very close to the $1.3 \%$ fall estimated in this analysis.

Among the four end-use categories, exports for private consumption have the largest decline (Table 2), 2\% from the base. Exports for private consumption to the United Kingdom account for $33 \%$ of Danish exports to the UK and decline by $19 \%$. Exports for intermediate use account for the majority of total Danish exports accounting for $57 \%$. Exports for intermediate use would decline by $1.2 \%$ with losses in the UK market of $17 \%$ from base levels. Of the total decline in Danish exports to the UK 55\% is accounted for by intermediate goods and $36 \%$ by good for private consumption (Table 2 ).

Capital goods exports would reduce by $1 \%$ overall and $15 \%$ to the UK under the Brexit scenario. Exports decrease to other partners, notably the EU, which account for $47 \%$ of Danish capital goods exported in the baseline. Exports of the important machinery and equipment make up $47 \%$ of Danish exports to the UK for capital use.

\section{Conclusions}

As a small open economy with strong trade links to the United Kingdom, Denmark is exposed to any increase in barriers to trade between the United Kingdom and EU. This paper considers an illustrative scenario in which trade relations between the EU and the United Kingdom default to operating along WTO MFN rules, along with non-tariff cost increases due to eventual regulatory divergence. The key transmission channel for Brexit to affect Denmark is through trade. This paper employs the extensive and detailed METRO trade model to quantify the trade impact of the scenario on the Danish economy both at the sectoral and the overall level.

The METRO simulation shows a sharp reduction of $17 \%$ in Danish exports to the United Kingdom and a decline in GDP of $1.3 \%$ in the WTO scenario. Considerable variation is seen in the impact across the different sectors of the Danish economy. The agri-food, smaller manufacturing, and machinery and equipment sectors are the most severely affected. The agri-food, and machinery and equipment sectors account for $51 \%$ of the fall 
in total Danish exports to the UK. Exports from the agri-food sector to the UK would fall by $24 \%$. At the sub-sector level, this fall is driven by a $32 \%$ decline in the exports of the meat products sub-sector and a $21 \%$ decline in processed foods. These sub-sectors are particularly negatively affected due to the concentration of their exports into the United Kingdom market and the comparatively high tariffs their products would face under a WTO schedule.

The exports to the UK of smaller manufacturing and metals sectors would fall by over $20 \%$. Denmark's large machinery and equipment sector, which relies on the UK for $10 \%$ of its export market, would have a $17 \%$ reduction in exports to the UK and a $1.4 \%$ fall in production. The chemicals sector, which includes pharmaceuticals, comprises $9.5 \%$ of Danish exports to the UK, and would experience an $18 \%$ reduction in its exports to the UK and a $1.1 \%$ decline in overall exports.

Not all sectors would be negatively affected, with a number of sectors experiencing a slight increase in total exports due to an increase in exports to the rest of the EU. Notably the financial and insurance sector sees both an increase in total exports of $0.9 \%$ and an increase in production of $0.5 \%$. The smaller sub-sectors of motor vehicles and parts and gas also see an increase in total exports of 3\% and 7\% respectively

Denmark is highly integrated in production networks through global value chains. It is estimated that the imposition of WTO tariffs and the rise in trade costs from NTM's would hamper Denmark's assess to intermediate imports from the UK, resulting in an $18 \%$ decline in these imports in the scenario.

The trade model also shows how the fall in export demand could affect production in different sectors. The highly UK-exposed agri-food sector would have a 3\% fall in output. This fall in output in the agri-food sector would lead to a $10.6 \%$ decline in the value of agricultural land. The largest proportional employment reductions are also concentrated in the agri-food, metals and materials manufacturing sectors. These sectors have a comparatively high share of workers in the lower skilled category, making the adjustment to the shock difficult as low-skilled workers tend to be the least mobile in the labour market. 


\section{References}

Aguiar, A., B. Narayanan and R. McDougall (2016), “An Overview of the GTAP 9 Data Base”, Journal of Global Economic Analysis, No. 1, pp. 181-208.

Arriola, C., C. Carrico., D. Haugh., N. Pain., E. Rusticelli., D. Smith., F. van Tongeren., and B. Westmore (2018), "The Potential Macroeconomic and Sectoral Consequences of Brexit on Ireland", OECD Economics Department Working Papers, No. 1508, OECD Publishing, Paris, https://doi.org/10.1787/8eddfa18-en.

Bellora, C., Emlinger, C., Fouré, J. and Guimbard, H. (2017), "Research for AGRI Committee, EU - UK agricultural trade: state of play and possible impacts of Brexit", European Parliament, Policy Department for Structural and Cohesion Policies, Brussels.

Bergin, A., Rodriguez, A.G., Morgenroth, E., and D. Smith (2017), "Modelling the Medium- to LongTerm Potential Macroeconomic Impact of Brexit on Ireland", Economic and Social Review, Vol. 48 Sep, No. 3, pp. 305-316.

Danish Ministry of Finance (2016), Økonomisk Redegørelse (Economic Survey), Copenhagen, May.

Dhingra, S., H. Huang, G. Ottaviano, J. Pessoa, T. Sampson and J. Van Reenen (2016) "The Costs and Benefits of Leaving the EU", Centre for Economic Performance Technical Report.

Ebel, M. og J. Warren (2016), “The Long-Term Economic Impact of Leaving the EU”, National Institute of Social and Economic Review, No. 236, May.

Erken, H., R. Hayat, M. Heijmerikx, C. Prins and De Vreede I. (2017), “Assessing the Economic Impact of Brexit: Backround Report", RaboResearch - Economic Research, Rabobank.

Fontagné, L., C. Mitaritonna and J. Signoret (2016), "Estimated Tariff Equivalents of Services NTMs", CEPII Working Paper, No. 2016-20, August.

Hufbauer, G.C. and J.J. Schott (2009), "Fitting Asia-Pacific Agreements into the WTO system", in Baldwin, R., and P. Low (eds.) Multilateralizing Regionalism: Challenges for the Global Trading System, Cambridge: Cambridge University Press.

Hauch, J., N. Kaarsen and L. L. Münier (2017), Danmark 2027, Copenhagen.

International Monetary Fund (2016), "United Kingdom Selected Issues”, IMF Country Report, No.16/169.

International Monetary Fund (2018), "Euro Area Policies Selected Issues", IMF Country Report, No.18/224.

Kierzenkowski, R., N. Pain, E. Rusticelli and S. Zwart (2016), "The Economic Consequences of Brexit: A Taxing Decision", OECD Economic Policy Paper, No. 16, OECD Publishing, Paris, https://doi.org/10.1787/5jm0lsvdkf6k-en.

McDonald, S. and K.E. Thierfelder (2013), "Globe v2: A SAM Based Global CGE Model using GTAP Data", Model documentation. Available at: http://www.cgemod.org.uk/

OECD (2011), "The Impact of Trade Liberalisation on Jobs and Growth: Technical Note", OECD Trade Policy Working Papers, No. 107, OECD Publishing, Paris, http://dx.doi.org/10.1787/5kgj4jfj1nq2-en

OECD (2015), METRO v1 Model Documentation, TAD/TC/WP(2014)24/FINAL.

OECD (2018), "Estimating Ad Valorem Equivalents of Non-Tariff Measures: Combining Price-Based and Quantity-Based Approaches", OECD Trade Policy Papers, No. 215, OECD Publishing, Paris. http://dx.doi.org/10.1787/f3cd5bdc-en. 
Paczos, M. (2018), "Modelling the Economic Effects of Trade Policies: A Submission to the Treasury and International Trade Committees Inquiry into Implications of the UK's Approach to International Trade", NIESR Policy Papers, No. 007.

Rojas-Romagos, Hugo (2016), "Trade effects of Brexit for the Netherlands", CPB background document, June.

Thelle, M., E. R. Sunesen, T. Jeppesen, S. Wilke and B. M. Lumby (2017), "Scenarier for en fremtidig handelsaftale med UK og de mulige økonomiske effekter for Danmark", Copenhagen Economics.

Timmer, M. P., E. Dietzenbacher., B. Los., R. Stehrer., and G. J. de Vries (2015), “An Illustrated User Guide to the World Input-Output Database: the Case of Global Automotive Production", Review of International Economics, Vol. 23, pp. 575-605.

Vandenbussche, H., Connell, W., and W. Simons (2017), "Global Value Chains, Trade Shocks and Jobs: An Application to Brexit”, CEPR Discussion paper, No. 12303. 
Annex A.

Table A.1. Sector aggregation

\begin{tabular}{|c|c|}
\hline Sector & Sub-sectors \\
\hline \multirow[t]{6}{*}{ Agri-Food } & Agriculture \\
\hline & Vegetables and Fruits \\
\hline & Horticulture \\
\hline & Other foods \\
\hline & Meat products \\
\hline & Other processed foods \\
\hline \multirow[t]{5}{*}{ Energy \& Natural Resources } & Natural resources \\
\hline & Oil \\
\hline & Gas \\
\hline & Petroleum, coal products \\
\hline & Mineral products nec \\
\hline \multirow[t]{5}{*}{ Materials Manufacturing } & Textiles \\
\hline & Wearing apparel \\
\hline & Leather products \\
\hline & Wood products \\
\hline & Paper products publishing \\
\hline Chemicals & Chemical rubber plastic prods \\
\hline \multirow[t]{3}{*}{ Metals } & Ferrous metals \\
\hline & Metals nec \\
\hline & Metal products \\
\hline Motor vehicles & Motor vehicles and parts \\
\hline Transport equipment nec & Transport equipment nec \\
\hline Electronic equipment & Electronic equipment \\
\hline Machinery and equipment & Machinery and equipment nec \\
\hline Manufactures nec & Manufactures nec \\
\hline \multirow[t]{5}{*}{ Construction \& Utilities } & Construction \\
\hline & Gas manufacture distribution \\
\hline & Electricity \\
\hline & Water \\
\hline & Dwellings \\
\hline Trade & Trade \\
\hline \multirow[t]{4}{*}{ Transport \& Communication } & Transport nec \\
\hline & Sea transport \\
\hline & Air transport \\
\hline & Communication \\
\hline \multirow[t]{2}{*}{ Financial \& Insurance } & Financial services nec \\
\hline & Insurance \\
\hline Business services & Business services nec \\
\hline \multirow[t]{2}{*}{ Public Sector\& Other Services } & Recreation and other services \\
\hline & PubAdmin Defence Health Education \\
\hline
\end{tabular}


Table A.2. Share of Denmark's exports by sector and destination at baseline

\begin{tabular}{|c|c|c|c|c|c|c|c|c|c|c|c|c|}
\hline \multirow[b]{3}{*}{ Product } & \multicolumn{4}{|c|}{$\begin{array}{l}\text { Share of total DNK } \\
\text { exports by sector at base }\end{array}$} & \multicolumn{4}{|c|}{$\begin{array}{l}\text { Share of total DNK exports } \\
\text { in each sector by destination }\end{array}$} & \multicolumn{4}{|c|}{ Value at base } \\
\hline & \multirow[b]{2}{*}{ Total } & \multicolumn{3}{|c|}{ Destination } & \multicolumn{4}{|c|}{$\begin{array}{c}\text { Destination } \\
\end{array}$} & \multirow[b]{2}{*}{ Total } & \multicolumn{3}{|c|}{ Destination } \\
\hline & & UK & EU26 & USA & Total & UK & EU26 & USA & & UK & EU26 & USA \\
\hline Agriculture & 2.4 & 0.7 & 3.3 & 0.1 & 100 & 2.1 & 71 & 0.4 & 3516 & 73 & 2,498 & 16 \\
\hline Vegetables and Fruits & 0.2 & 0 & 0.2 & 0 & 100 & 1.6 & 69.8 & 0.2 & 235 & 4 & 164 & 0 \\
\hline Horticulture & 0.5 & 0.6 & 0.6 & 0.1 & 100 & 9.1 & 70.7 & 2.3 & 684 & 62 & 484 & 16 \\
\hline Other foods & 3.9 & 4.2 & 4.3 & 0.8 & 100 & 7.5 & 56.5 & 1.7 & 5,796 & 432 & 3,277 & 100 \\
\hline Meat products & 3.6 & 10.4 & 3.1 & 1.5 & 100 & 19.9 & 44.3 & 3.4 & 5,353 & 1,068 & 2,370 & 183 \\
\hline Other processed foods & 4.3 & 7.2 & 4.7 & 1.1 & 100 & 11.6 & 55.4 & 2.1 & 6,386 & 738 & 3,535 & 134 \\
\hline Natural resources & 0.1 & 0.1 & 0.1 & 0 & 100 & 5.2 & 70.5 & 0.6 & 155 & 8 & 109 & 1 \\
\hline Oil & 3 & 11.3 & 4.2 & 0 & 100 & 26.1 & 70.9 & 0.1 & 4,428 & 1,155 & 3,141 & 4 \\
\hline Gas & 0.3 & 0 & 0.6 & 0 & 100 & 0.3 & 92.9 & 0.5 & 487 & 1 & 453 & 3 \\
\hline Textiles & 1.2 & 1.4 & 1.7 & 0.3 & 100 & 7.9 & 69.5 & 1.9 & 1,819 & 144 & 1,263 & 35 \\
\hline Wearing apparel & 1.5 & 1.5 & 2 & 0 & 100 & 7 & 69.2 & 0.2 & 2,157 & 151 & 1,494 & 5 \\
\hline Leather products & 0.5 & 0.4 & 0.7 & 0 & 100 & 5.2 & 71.1 & 0.5 & 748 & 39 & 532 & 3 \\
\hline Wood products & 1.7 & 2 & 1.9 & 0.8 & 100 & 8.1 & 56.3 & 3.8 & 2,546 & 207 & 1,432 & 96 \\
\hline Paper products publishing & 1.1 & 0.7 & 1.4 & 0.2 & 100 & 4.7 & 68.4 & 1.9 & 1,559 & 73 & 1,067 & 30 \\
\hline Petroleum, coal products & 1.3 & 2.3 & 1.2 & 0.3 & 100 & 12.6 & 48.8 & 2.2 & 1,878 & 237 & 916 & 41 \\
\hline Chemical rubber plastic prods & 12.7 & 9.5 & 12.1 & 21.9 & 100 & 5.2 & 48.7 & 14.2 & 18,700 & 978 & 9,101 & 2,655 \\
\hline Mineral products nec & 0.7 & 0.4 & 0.7 & 0.3 & 100 & 3.7 & 51 & 3.3 & 1,072 & 39 & 547 & 36 \\
\hline Ferrous metals & 1.1 & 1 & 1.4 & 0.1 & 100 & 6.4 & 64.8 & 1.1 & 1,581 & 102 & 1,024 & 17 \\
\hline Metals nec & 0.7 & 0.3 & 1 & 0.2 & 100 & 2.9 & 78.6 & 2 & 1,004 & 29 & 789 & 20 \\
\hline Metal products & 2.6 & 7.4 & 2.5 & 1.1 & 100 & 20.1 & 50.1 & 3.6 & 3,777 & 758 & 1,894 & 135 \\
\hline Motor vehicles and parts & 1.6 & 1.1 & 2.3 & 0.4 & 100 & 4.6 & 70.3 & 1.9 & 2,423 & 111 & 1,703 & 45 \\
\hline Transport equipment nec & 0.8 & 0.4 & 0.5 & 0.6 & 100 & 3.8 & 32 & 6.8 & 1,113 & 43 & 356 & 75 \\
\hline Electronic equipment & 2.2 & 1.5 & 2.4 & 1.8 & 100 & 4.7 & 54.8 & 6.8 & 3,282 & 155 & 1,799 & 223 \\
\hline Machinery and equipment nec & 15.6 & 19 & 14.2 & 21.3 & 100 & 8.5 & 46.6 & 11.2 & 23,050 & 1,955 & 10,741 & 2,578 \\
\hline Manufactures nec & 1.3 & 1.2 & 1.5 & 2.5 & 100 & 6.6 & 60 & 16.2 & 1,866 & 123 & 1,120 & 303 \\
\hline Electricity & 0.6 & 0 & 0.9 & 0 & 100 & 0.4 & 69.4 & 0.6 & 944 & 3 & 655 & 6 \\
\hline Gas manufacture distribution & 0.3 & 0 & 0.4 & 0.1 & 100 & 1.1 & 70.7 & 2.1 & 378 & 4 & 267 & 8 \\
\hline Water & 0 & 0 & 0 & 0 & 100 & 4.3 & 53.4 & 6.9 & 31 & 1 & 17 & 2 \\
\hline Construction & 2.2 & 0.5 & 1.6 & 0.1 & 100 & 1.5 & 37.3 & 0.4 & 3,214 & 49 & 1,200 & 12 \\
\hline Trade & 3.1 & 0.6 & 3.2 & 0.6 & 100 & 1.4 & 53.1 & 1.7 & 4,512 & 65 & 2,394 & 76 \\
\hline Transport nec & 2.2 & 0.8 & 2.2 & 3.7 & 100 & 2.4 & 50.5 & 13.9 & 3,238 & 78 & 1,634 & 450 \\
\hline Sea transport & 1.7 & 1 & 1.2 & 0.1 & 100 & 3.9 & 34.7 & 0.7 & 2,548 & 100 & 885 & 17 \\
\hline Air transport & 3.7 & 2.6 & 3.3 & 6.5 & 100 & 4.8 & 44.7 & 14.2 & 5,527 & 264 & 2,471 & 783 \\
\hline Communication & 2.2 & 2.1 & 2.4 & 1.8 & 100 & 6.6 & 56.2 & 6.6 & 3,224 & 212 & 1,812 & 214 \\
\hline Financial services nec & 2.9 & 1.6 & 3.3 & 5.4 & 100 & 3.8 & 57.8 & 15.1 & 4,292 & 162 & 2,481 & 649 \\
\hline Insurance & 2.4 & 0.5 & 1.2 & 7.7 & 100 & 1.4 & 24.1 & 25.9 & 3,617 & 49 & 872 & 935 \\
\hline Business services nec & 9.6 & 3.5 & 9.7 & 6.5 & 100 & 2.5 & 51.7 & 5.6 & 14,193 & 357 & 7,343 & 790 \\
\hline Recreation and other services & 1.5 & 1.3 & 1 & 0.3 & 100 & 6 & 34.6 & 1.9 & 2,217 & 132 & 767 & 42 \\
\hline PubAdmin Defence Health Educat & 2.9 & 1 & 1.1 & 11.2 & 100 & 2.5 & 19.4 & 32.1 & 4,232 & 105 & 822 & 1,358 \\
\hline Dwellings & 0 & 0 & 0 & 0 & - & - & - & - & - & - & - & - \\
\hline Total & 100 & 100 & 100 & 100 & 100 & 6.9 & 51 & 8.2 & 147,783 & 10,266 & 75,429 & 12,097 \\
\hline
\end{tabular}

Note: 2011 GTAP data used. 
Table A.3. Share of Denmark's imports by sector and origin at baseline

\begin{tabular}{|c|c|c|c|c|c|c|c|c|c|c|c|c|}
\hline \multirow[b]{3}{*}{ Product } & \multicolumn{4}{|c|}{$\begin{array}{l}\text { Share of total DNK imports } \\
\text { by sector at base }\end{array}$} & \multicolumn{4}{|c|}{$\begin{array}{l}\text { Share of total DNK imports in } \\
\text { each sector by original base }\end{array}$} & \multicolumn{4}{|c|}{ Value at base } \\
\hline & \multicolumn{4}{|c|}{ Origin } & \multicolumn{4}{|c|}{$\begin{array}{c}\text { Origin } \\
\end{array}$} & \multicolumn{4}{|c|}{ Origin } \\
\hline & Total & UK & EU26 & USA & Total & UK & EU26 & USA & Total & UK & EU26 & USA \\
\hline Agriculture & 1.3 & 0.6 & 1.3 & 0.3 & 100 & 3.2 & 60.7 & 1.1 & 1816 & 57 & 1103 & 19 \\
\hline Vegetables and Fruits & 0.7 & 0.1 & 0.9 & 0.5 & 100 & 1.4 & 84.9 & 4.1 & 916 & 13 & 778 & 38 \\
\hline Horticulture & 0.4 & 0.1 & 0.5 & 0.1 & 100 & 1.6 & 68.9 & 1.4 & 588 & 9 & 405 & 8 \\
\hline Other foods & 3 & 1.9 & 3.5 & 1 & 100 & 4.3 & 68.8 & 1.6 & 4220 & 183 & 2905 & 69 \\
\hline Meat products & 0.9 & 0.4 & 1.2 & 0.6 & 100 & 3.2 & 82.4 & 3.5 & 1228 & 39 & 1012 & 42 \\
\hline Other processed foods & 3.5 & 1.9 & 3.8 & 1.5 & 100 & 3.8 & 64.6 & 2.1 & 4902 & 186 & 3167 & 101 \\
\hline Natural resources & 0.5 & 0.1 & 0.1 & 0.2 & 100 & 0.8 & 14 & 1.9 & 739 & 6 & 103 & 14 \\
\hline Oil & 0.8 & 1.1 & 0 & 0 & 100 & 10.2 & 0 & 0 & 1074 & 110 & 0 & 0 \\
\hline Gas & 0.1 & 0 & 0 & 0 & 100 & 0 & 1.3 & 0 & 174 & 0 & 2 & 0 \\
\hline Textiles & 1.7 & 0.9 & 1.2 & 0.2 & 100 & 3.8 & 43.6 & 0.6 & 2364 & 91 & 1031 & 15 \\
\hline Wearing apparel & 2.2 & 0.7 & 1.2 & 0.2 & 100 & 2.1 & 32.7 & 0.4 & 3071 & 63 & 1004 & 11 \\
\hline Leather products & 0.9 & 0.4 & 0.8 & 0.1 & 100 & 3.2 & 50.8 & 0.3 & 1272 & 41 & 646 & 4 \\
\hline Wood products & 2.2 & 0.4 & 2.8 & 0.4 & 100 & 1.4 & 74.5 & 1 & 3150 & 43 & 2347 & 31 \\
\hline Paper products publishing & 1.8 & 1 & 2.7 & 0.6 & 100 & 3.9 & 86.3 & 1.6 & 2561 & 99 & 2211 & 41 \\
\hline Petroleum, coal products & 4.7 & 6.3 & 2.3 & 3.8 & 100 & 9.2 & 28.3 & 3.9 & 6596 & 608 & 1868 & 259 \\
\hline Chemical rubber plastic prods & 9.2 & 9.1 & 11.9 & 4.8 & 100 & 6.8 & 76.2 & 2.6 & 12930 & 879 & 9852 & 332 \\
\hline Mineral products nec & 0.9 & 0.4 & 1.2 & 0.4 & 100 & 3.3 & 76.6 & 2.3 & 1275 & 43 & 976 & 30 \\
\hline Ferrous metals & 2.2 & 0.9 & 2.4 & 0.2 & 100 & 2.9 & 62.1 & 0.5 & 3143 & 90 & 1953 & 15 \\
\hline Metals nec & 1 & 0.5 & 1.1 & 0.2 & 100 & 3.4 & 66.6 & 0.8 & 1348 & 45 & 898 & 10 \\
\hline Metal products & 2.2 & 1.2 & 2.9 & 0.4 & 100 & 3.6 & 75.7 & 1 & 3150 & 114 & 2386 & 31 \\
\hline Motor vehicles and parts & 4.6 & 2.5 & 6.5 & 0.5 & 100 & 3.8 & 83.6 & 0.5 & 6434 & 244 & 5376 & 35 \\
\hline Transport equipment nec & 1.5 & 2.4 & 0.8 & 5.5 & 100 & 10.8 & 32.6 & 17.9 & 2127 & 230 & 694 & 380 \\
\hline Electronic equipment & 5 & 3.3 & 4.9 & 2.3 & 100 & 4.6 & 57.2 & 2.3 & 7013 & 319 & 4010 & 161 \\
\hline Machinery and equipment nec & 11.6 & 11.5 & 13.9 & 12.1 & 100 & 6.8 & 70.4 & 5.1 & 16292 & 1109 & 11470 & 831 \\
\hline Manufactures nec & 1.2 & 1.1 & 0.9 & 0.6 & 100 & 6.2 & 43.1 & 2.4 & 1693 & 106 & 729 & 40 \\
\hline Electricity & 0.6 & 0 & 0.7 & 0 & 100 & 0.2 & 68.6 & 0.3 & 863 & 2 & 593 & 3 \\
\hline Gas manufacture distribution & 0 & 0 & 0 & 0 & 100 & 9 & 18.4 & 9.9 & 6 & 1 & 1 & 1 \\
\hline Water & 0 & 0 & 0 & 0 & 100 & 5.1 & 47.7 & 9.3 & 30 & 2 & 14 & 3 \\
\hline Construction & 2.4 & 1.7 & 2.2 & 5.3 & 100 & 4.9 & 55 & 10.9 & 3360 & 164 & 1849 & 365 \\
\hline Trade & 3.4 & 2.4 & 3.4 & 1.4 & 100 & 4.8 & 58.3 & 2 & 4845 & 235 & 2824 & 97 \\
\hline Transport nec & 2.6 & 0.8 & 2 & 4.6 & 100 & 2.1 & 45.8 & 8.7 & 3598 & 74 & 1646 & 314 \\
\hline Sea transport & 1.4 & 1.6 & 0.8 & 0.3 & 100 & 7.8 & 34.1 & 1 & 1943 & 152 & 663 & 20 \\
\hline Air transport & 3.3 & 2.6 & 3 & 5.1 & 100 & 5.5 & 54.4 & 7.6 & 4589 & 253 & 2496 & 349 \\
\hline Communication & 2.1 & 2 & 2.1 & 2.3 & 100 & 6.3 & 57.3 & 5.4 & 2990 & 189 & 1713 & 161 \\
\hline Financial services nec & 4.1 & 9.4 & 4.1 & 6.7 & 100 & 15.9 & 59.5 & 8.1 & 5701 & 907 & 3392 & 464 \\
\hline Insurance & 1.9 & 1.9 & 2 & 4.2 & 100 & 7.1 & 61.7 & 10.9 & 2649 & 189 & 1635 & 289 \\
\hline Business services nec & 10.1 & 22.8 & 8.1 & 17 & 100 & 15.5 & 46.8 & 8.2 & 14215 & 2204 & 6660 & 1168 \\
\hline Recreation and other services & 1.7 & 4.5 & 1.1 & 2.5 & 100 & 18.1 & 38.9 & 7.1 & 2414 & 436 & 938 & 172 \\
\hline PubAdmin Defence Health Educat & 2.3 & 1.5 & 1.5 & 14 & 100 & 4.3 & 38.8 & 29.5 & 3262 & 141 & 1265 & 962 \\
\hline Dwellings & 0 & 0 & 0 & 0 & - & - & - & - & - & - & - & - \\
\hline Total & 100 & 100 & 100 & 100 & 100 & 6.9 & 58.8 & 4.9 & 140540 & 9673 & 82616 & 6885 \\
\hline
\end{tabular}

Note: 2011 GTAP data used. 
Table A.4. Denmark's gross exports by product and destination

$\%$ change from value at baseline

\begin{tabular}{|c|c|c|c|c|}
\hline & \multicolumn{4}{|c|}{ Destination } \\
\hline & Total & UK & EU & USA \\
\hline Agriculture & -1.2 & -11.8 & -1.0 & -0.9 \\
\hline Vegetables and Fruits & 0.8 & -16.9 & 1.1 & 0.0 \\
\hline Horticulture & -1.1 & -10.5 & -0.4 & 0.3 \\
\hline Other foods & -0.6 & -12.1 & 0.2 & 0.4 \\
\hline Meat products & -7.9 & -32.4 & -2.5 & -0.7 \\
\hline Other processed foods & -3.6 & -21.1 & -1.3 & -1.5 \\
\hline Natural resources & -1.4 & -12.7 & -1.1 & 0.0 \\
\hline Oil & -0.4 & -7.0 & 2.0 & 0.0 \\
\hline Gas & 7.1 & -16.4 & 7.7 & 0.4 \\
\hline Textiles & -3.1 & -22.3 & -1.4 & -0.5 \\
\hline Wearing apparel & -3.9 & -39.5 & -1.1 & 0.0 \\
\hline Leather products & -1.2 & -21.6 & -0.2 & 0.0 \\
\hline Wood products & -3.5 & -29.1 & -1.5 & -1.0 \\
\hline Paper products publishing & -1.4 & -14.8 & -1.0 & -0.6 \\
\hline Petroleum, coal products & -0.7 & -9.3 & 0.4 & -0.1 \\
\hline Chemical rubber plastic prods & -1.1 & -17.9 & -0.2 & -0.5 \\
\hline Mineral products nec & -1.4 & -21.6 & -0.9 & -0.5 \\
\hline Ferrous metals & -1.7 & -14.9 & -1.1 & 0.1 \\
\hline Metals nec & -0.8 & -19.3 & -0.3 & -0.1 \\
\hline Metal products & -5.2 & -21.5 & -1.4 & -0.9 \\
\hline Motor vehicles and parts & 3.2 & -12.3 & 4.7 & 0.1 \\
\hline Transport equipment nec & -0.7 & -23.9 & -0.2 & 0.6 \\
\hline "Electronic equipment & -1.1 & -15.6 & -0.5 & -0.1 \\
\hline Machinery and equipment nec & -1.7 & -17.3 & -0.6 & -0.4 \\
\hline Manufactures nec & -1.6 & -16.1 & -0.7 & -0.6 \\
\hline Electricity & -0.9 & -9.8 & -1.1 & -0.2 \\
\hline Gas manufacture distribution & -0.7 & -9.7 & -0.9 & -0.4 \\
\hline Water & -1.3 & -11.9 & -1.1 & -0.9 \\
\hline Construction & -1.0 & -18.3 & -0.9 & -0.6 \\
\hline Trade & -0.8 & -8.0 & -0.8 & -0.5 \\
\hline Transport nec & -0.9 & -8.0 & -1.0 & -0.4 \\
\hline Sea transport & -0.5 & -5.2 & -0.1 & -0.4 \\
\hline Air transport & 0.0 & -5.6 & 0.4 & 0.1 \\
\hline Communication & -0.4 & -9.2 & 0.8 & -0.5 \\
\hline Financial services nec & 2.4 & -7.0 & 5.0 & -0.6 \\
\hline Insurance & -0.9 & -10.6 & -0.9 & -0.8 \\
\hline Business services nec & -0.5 & -16.4 & 0.2 & -0.4 \\
\hline Recreation and other services & -1.2 & -8.9 & -1.1 & -0.4 \\
\hline PubAdmin Defence Health Educat & -1.3 & -13.2 & -1.8 & -0.7 \\
\hline \multicolumn{5}{|l|}{ Dwellings } \\
\hline Total & -1.4 & -17.4 & -0.1 & -0.5 \\
\hline
\end{tabular}


Table A.5. Sector shares of total production in each region

\begin{tabular}{|c|c|c|}
\hline Sector & Denmark & European Union \\
\hline Agriculture & 2.1 & 1.2 \\
\hline Vegetables and Fruits & 0.1 & 0.3 \\
\hline Horticulture & 0.3 & 0.2 \\
\hline Other foods & 2.2 & 2 \\
\hline Meat products & 1.1 & 0.5 \\
\hline Other processed foods & 1.8 & 1.8 \\
\hline Natural resources & 0.1 & 0.4 \\
\hline Oil & 1.5 & 0.1 \\
\hline Gas & 0.2 & 0.1 \\
\hline Textiles & 0.4 & 0.6 \\
\hline Wearing apparel & 0.4 & 0.3 \\
\hline Leather products & 0.1 & 0.3 \\
\hline Wood products & 0.7 & 0.7 \\
\hline Paper products publishing & 1.2 & 1.8 \\
\hline Petroleum, coal products & 1.1 & 2.2 \\
\hline Chemical rubber plastic prods & 4.1 & 5 \\
\hline Mineral products nec & 0.5 & 0.9 \\
\hline Ferrous metals & 0.4 & 1.2 \\
\hline Metals nec & 0.2 & 0.8 \\
\hline Metal products & 1.6 & 1.9 \\
\hline Motor vehicles and parts & 0.5 & 3 \\
\hline Transport equipment nec & 0.2 & 0.8 \\
\hline Electronic equipment & 0.7 & 1 \\
\hline Machinery and equipment nec & 10 & 5.5 \\
\hline Manufactures nec & 0.6 & 1.1 \\
\hline Electricity & 1.6 & 1.8 \\
\hline Gas manufacture distribution & 0.2 & 0.1 \\
\hline Water & 0.1 & 0.2 \\
\hline Construction & 4 & 6.8 \\
\hline Trade & 9.1 & 11.7 \\
\hline Transport nec & 4.3 & 4.7 \\
\hline Sea transport & 1.8 & 0.8 \\
\hline Air transport & 1.4 & 0.8 \\
\hline Communication & 2.2 & 2 \\
\hline Financial services nec & 4.5 & 3.4 \\
\hline Insurance & 1.5 & 1.2 \\
\hline Business services nec & 13.8 & 14.6 \\
\hline Recreation and other services & 2.5 & 2.5 \\
\hline PubAdmin Defence Health Educat & 18 & 12.5 \\
\hline Dwellings & 2.8 & 3.3 \\
\hline Total & 100 & 100 \\
\hline
\end{tabular}


Table A.6. Production effects

$\%$ change from value at baseline

\begin{tabular}{|c|c|c|}
\hline Sector & Denmark & European Union \\
\hline Agriculture & -2.8 & -0.7 \\
\hline Vegetables and Fruits & -0.1 & -1 \\
\hline Horticulture & -1.1 & -0.8 \\
\hline Other foods & -0.9 & -0.6 \\
\hline Meat products & -7 & -1.2 \\
\hline Other processed foods & -3.2 & -0.9 \\
\hline Natural resources & -1.5 & -0.6 \\
\hline Oil & -0.2 & 0 \\
\hline Gas & 3.4 & 2.3 \\
\hline Textiles & -2.9 & -1 \\
\hline Wearing apparel & -3.7 & -2.1 \\
\hline Leather products & -1.3 & -1.3 \\
\hline Wood products & -3.1 & -1.6 \\
\hline Paper products publishing & -1.3 & -0.8 \\
\hline Petroleum, coal products & -0.4 & -0.6 \\
\hline Chemical rubber plastic prods & -1.1 & -1 \\
\hline Mineral products nec & -1.4 & -0.8 \\
\hline Ferrous metals & -1.8 & -0.5 \\
\hline Metals nec & -0.8 & -1.6 \\
\hline Metal products & -3.3 & -0.8 \\
\hline Motor vehicles and parts & 2.6 & 0.6 \\
\hline Transport equipment nec & -1 & -0.8 \\
\hline Electronic equipment & -1.1 & -1.6 \\
\hline Machinery and equipment nec & -1.4 & -0.7 \\
\hline Manufactures nec & -1.6 & -0.9 \\
\hline Electricity & -1 & -0.7 \\
\hline Gas manufacture distribution & -1 & -0.5 \\
\hline Water & -1 & -0.6 \\
\hline Construction & -1.1 & -0.8 \\
\hline Trade & -1 & -0.6 \\
\hline Transport nec & -0.9 & -0.7 \\
\hline Sea transport & -0.4 & -0.2 \\
\hline Air transport & -0.1 & -0.7 \\
\hline Communication & -0.6 & -0.4 \\
\hline Financial services nec & 1 & 0.3 \\
\hline Insurance & -1 & -0.6 \\
\hline Business services nec & -0.7 & -0.5 \\
\hline Recreation and other services & -1.3 & -0.6 \\
\hline PubAdmin Defence Health Educat & -1.8 & -1.3 \\
\hline Dwellings & -0.3 & -0.1 \\
\hline
\end{tabular}


Table A.7. Aggregate factor demand across regions

Value at baseline, million USD

\begin{tabular}{lrrrrrrrr}
\hline & Land & $\begin{array}{c}\text { Technical and } \\
\text { Assistant } \\
\text { Professionals }\end{array}$ & Clerks & $\begin{array}{c}\text { Service and } \\
\text { shop } \\
\text { assistants }\end{array}$ & $\begin{array}{c}\text { Office managers } \\
\text { and } \\
\text { Professionals }\end{array}$ & $\begin{array}{c}\text { Agricultural and } \\
\text { other low skilled } \\
\text { workers }\end{array}$ & Capital & $\begin{array}{c}\text { Natural } \\
\text { Resources }\end{array}$ \\
\hline $\begin{array}{l}\text { European } \\
\text { Union }\end{array}$ & 55,732 & 44,057 & 29,139 & 38,729 & 57,135 & 59,900 & $6,149,761$ & 27,752 \\
\begin{tabular}{l} 
Denmark \\
\hline 112
\end{tabular} & 784 & 394 & 589 & 813 & 596 & 98,529 & 2,906 \\
\hline
\end{tabular}


Table A.8. Per cent change in factor demand in Denmark by sector and factor

\begin{tabular}{|c|c|c|c|c|c|c|c|c|}
\hline & Land & $\begin{array}{l}\text { Technical } \\
\text { and } \\
\text { assistant } \\
\text { professionals }\end{array}$ & Clerks & $\begin{array}{c}\text { Service } \\
\text { and shop } \\
\text { assistants }\end{array}$ & $\begin{array}{c}\text { Office } \\
\text { managers and } \\
\text { professionals }\end{array}$ & $\begin{array}{l}\text { Agricultural } \\
\text { and other } \\
\text { low skilled } \\
\text { workers }\end{array}$ & Capital & $\begin{array}{l}\text { Natural } \\
\text { resources }\end{array}$ \\
\hline Agriculture & -0.3 & -4.3 & -3.4 & -3.4 & -4.4 & -3.1 & -2.7 & -2.8 \\
\hline Vegetables and Fruits & 2.5 & 0 & 0 & 0 & 0 & -0.3 & -0.1 & \\
\hline Horticulture & 1.5 & -2.5 & 0 & -5.9 & -2.7 & -1.4 & -1 & \\
\hline Other food products & & -1.9 & -1.3 & -1.3 & -2 & -1.2 & -0.2 & \\
\hline Meat products & & -7.3 & -7 & -9.1 & -7.7 & -7.4 & -5.9 & \\
\hline Processed foods & & -3.6 & -3.1 & -3.4 & -3.6 & -3.3 & -1.9 & \\
\hline Natural resources & & -2.5 & 0 & 0 & 0 & -1.9 & -0.8 & -1.3 \\
\hline Oil & & -2.5 & 0 & 0 & 0 & 0 & -0.2 & -0.1 \\
\hline Gas & & 9.1 & 0 & 0 & 0 & 14.3 & 3.4 & 3.5 \\
\hline Textiles & & -3.4 & -3 & 0 & -3.6 & -3.3 & -1.7 & \\
\hline Wearing apparel & & -3.8 & -4.3 & 0 & -5 & -4.1 & -2.7 & \\
\hline Leather products & & -3.8 & -8.3 & 0 & 0 & -2.4 & -0.1 & \\
\hline Wood products & & -3.7 & -3.1 & -2.4 & -3.3 & -3.3 & -1.8 & \\
\hline $\begin{array}{l}\text { Paper products } \\
\text { publishing }\end{array}$ & & -1.9 & -1.4 & -1.8 & -1.9 & -1.4 & -0.1 & \\
\hline $\begin{array}{l}\text { Petroleum, coal } \\
\text { products }\end{array}$ & & 0 & 0 & 0 & -3.8 & 0 & 0 & \\
\hline $\begin{array}{l}\text { Chemical rubber } \\
\text { plastic prods }\end{array}$ & & -2.1 & -1.4 & -1.2 & -2.1 & -1.4 & -0.4 & \\
\hline Mineral products nec & & -1.8 & -1.5 & -2 & -1.7 & -1.4 & -0.1 & \\
\hline Ferrous metals & & -2.1 & -1.9 & 0 & -2.2 & -1.8 & -0.4 & \\
\hline Metals nec & & -0.9 & -2 & 0 & -0.9 & -0.5 & 0.6 & \\
\hline Metal products & & -3.7 & -3.5 & -2.9 & -3.6 & -3.3 & -2 & \\
\hline $\begin{array}{l}\text { Motor vehicles and } \\
\text { parts }\end{array}$ & & 1.7 & 2.6 & 0 & 1.8 & 2.5 & 3.8 & \\
\hline $\begin{array}{l}\text { Transport equipment } \\
\text { nec }\end{array}$ & & -1.1 & -1.3 & 0 & -1.8 & -1 & 0.2 & \\
\hline Electronic equipment & & -2.2 & -1 & 0 & -1.9 & -1.3 & -0.2 & \\
\hline $\begin{array}{l}\text { Machinery and } \\
\text { equipment nec }\end{array}$ & & -1.9 & -1.5 & -1.5 & -1.9 & -1.5 & -0.3 & \\
\hline Manufactures nec & & -2.1 & -1.6 & 0 & -2.2 & -1.7 & -0.7 & \\
\hline Electricity & & -2.1 & -1.3 & 0 & -2 & -1.4 & -0.6 & \\
\hline $\begin{array}{l}\text { Gas manufacture } \\
\text { distribution }\end{array}$ & & -1.9 & 0 & 0 & -3.2 & -1.5 & -0.7 & \\
\hline Water & & -2.5 & -2.7 & 0 & -2.1 & -1 & -0.5 & \\
\hline Construction & & -1.7 & -1.2 & -1.8 & -1.6 & -1.2 & 0 & \\
\hline Trade & & -1.5 & -1.2 & -1.2 & -1.5 & -1.2 & 0.2 & \\
\hline Transport nec & & -1.5 & -1.2 & -0.9 & -1.5 & -1.1 & 0.2 & \\
\hline Sea transport & & -1.2 & -1 & -3.8 & -1.1 & 0 & 0.4 & \\
\hline Air transport & & -0.5 & -0.3 & 0 & -0.6 & -1 & 1.3 & \\
\hline Communication & & -1.3 & -0.8 & -1 & -1.3 & -0.6 & 0.4 & \\
\hline Financial services nec & & 0.2 & 0.8 & 1.6 & 0.2 & 1 & 1.9 & \\
\hline Insurance & & -1.2 & -1.1 & 0 & -1.1 & -2.6 & 0.5 & \\
\hline Business services nec & & -1.4 & -0.8 & -0.9 & -1.4 & -0.9 & 0.3 & \\
\hline $\begin{array}{l}\text { Recreation and other } \\
\text { services }\end{array}$ & & -2.1 & -1.8 & -1.3 & -2.3 & -1.5 & -0.6 & \\
\hline $\begin{array}{l}\text { PubAdmin Defence } \\
\text { Health Educat }\end{array}$ & & -2.1 & -1.9 & -1.9 & -2.1 & -1.9 & -0.4 & \\
\hline Dwellings & & -1.6 & 0 & -1.7 & -1.6 & 0 & -0.2 & \\
\hline
\end{tabular}


Table A.9. Factor demand by sector at baseline, million USD

\begin{tabular}{|c|c|c|c|c|c|c|c|c|}
\hline & Land & $\begin{array}{l}\text { Technical } \\
\text { and } \\
\text { assistant } \\
\text { professionals }\end{array}$ & Clerks & $\begin{array}{c}\text { Service } \\
\text { and shop } \\
\text { assistants }\end{array}$ & $\begin{array}{c}\text { Office } \\
\text { managers and } \\
\text { professionals }\end{array}$ & $\begin{array}{l}\text { Agricultural } \\
\text { and other } \\
\text { low skilled } \\
\text { workers }\end{array}$ & Capital & $\begin{array}{l}\text { Natural } \\
\text { resources }\end{array}$ \\
\hline Agriculture & 602.4 & 1.8 & 1.2 & 0.9 & 5.4 & 56 & 2302.9 & 256.8 \\
\hline Vegetables and Fruits & 37.8 & 0.1 & 0.1 & 0 & 0.3 & 2.9 & 129.6 & \\
\hline Horticulture & 71.6 & 0.4 & 0.3 & 0.2 & 1.1 & 11.1 & 233.2 & \\
\hline Other food products & & 7 & 3.1 & 0.8 & 6.6 & 11.4 & 1563.6 & \\
\hline Meat products & & 1.9 & 0.9 & 0.2 & 1.8 & 3.1 & 121.4 & \\
\hline Processed foods & -1.6 & 5.1 & 2.3 & 0.6 & 4.8 & 8.2 & 416.4 & \\
\hline Natural resources & & 0.8 & 0.2 & 0.1 & 0.2 & 0.5 & 95.3 & 38.4 \\
\hline Oil & & 1.2 & 0.3 & 0.1 & 0.3 & 0.8 & 4529.7 & 2310.6 \\
\hline Gas & & 0.1 & 0 & 0 & 0 & 0.1 & 566.2 & 300.3 \\
\hline Textiles & & 1.5 & 0.7 & 0.2 & 1.4 & 2.4 & 172.1 & \\
\hline Wearing apparel & & 1.1 & 0.5 & 0.1 & 1 & 1.7 & 161.6 & \\
\hline Leather products & & 0.3 & 0.1 & 0 & 0.2 & 0.4 & 39.9 & \\
\hline Wood products & & 3.6 & 1.6 & 0.4 & 3.4 & 5.8 & 256.8 & \\
\hline $\begin{array}{l}\text { Paper products } \\
\text { publishing }\end{array}$ & & 9.7 & 4.4 & 1.1 & 9.2 & 15.8 & 772.9 & \\
\hline $\begin{array}{l}\text { Petroleum, coal } \\
\text { products }\end{array}$ & & 0.3 & 0.1 & 0 & 0.3 & 0.4 & 98.4 & \\
\hline $\begin{array}{l}\text { Chemical rubber } \\
\text { plastic prods }\end{array}$ & & 14.4 & 6.5 & 1.7 & 13.6 & 23.4 & 5778.4 & \\
\hline Mineral products nec & & 4.3 & 2 & 0.5 & 4.1 & 7.1 & 218.3 & \\
\hline Ferrous metals & & 2.4 & 1.1 & 0.3 & 2.2 & 3.9 & 59.7 & \\
\hline Metals nec & & 1.1 & 0.5 & 0.1 & 1.1 & 1.8 & 38.7 & \\
\hline Metal products & & 9 & 4 & 1 & 8.5 & 14.7 & 652.4 & \\
\hline $\begin{array}{l}\text { Motor vehicles and } \\
\text { parts }\end{array}$ & & 1.7 & 0.8 & 0.2 & 1.6 & 2.8 & 266.9 & \\
\hline $\begin{array}{l}\text { Transport equipment } \\
\text { nec }\end{array}$ & & 1.8 & 0.8 & 0.2 & 1.7 & 2.9 & 98.4 & \\
\hline Electronic equipment & & 2.3 & 1 & 0.3 & 2.2 & 3.7 & 785.3 & \\
\hline $\begin{array}{l}\text { Machinery and } \\
\text { equipment nec }\end{array}$ & & 23.4 & 10.5 & 2.7 & 22.1 & 38.1 & 6828.5 & \\
\hline Manufactures nec & & 2.8 & 1.3 & 0.3 & 2.7 & 4.6 & 528 & \\
\hline Electricity & & 3.3 & 1.5 & 0.3 & 2 & 4.3 & 3561 & \\
\hline $\begin{array}{l}\text { Gas manufacture } \\
\text { distribution }\end{array}$ & & 0.5 & 0.2 & 0 & 0.3 & 0.7 & 416.3 & \\
\hline Water & & 0.8 & 0.4 & 0.1 & 0.5 & 1 & 274.3 & \\
\hline Construction & & 14 & 8.9 & 0.6 & 20 & 155.7 & 1586.9 & \\
\hline Trade & & 83.4 & 59.9 & 194.5 & 105 & 54 & 7340.2 & \\
\hline Transport nec & & 20.2 & 26 & 3.2 & 11.3 & 3.5 & 3079.9 & \\
\hline Sea transport & & 1.6 & 2.1 & 0.3 & 0.9 & 0.3 & 1231.5 & \\
\hline Air transport & & 5.9 & 7.6 & 0.9 & 3.3 & 1 & 426.2 & \\
\hline Communication & & 19.6 & 25.2 & 3.1 & 10.9 & 3.4 & 2170.9 & \\
\hline Financial services nec & & 32.9 & 21.9 & 0.6 & 20.3 & 1 & 7462.4 & \\
\hline Insurance & & 12.9 & 8.6 & 0.3 & 7.9 & 0.4 & 505.2 & \\
\hline Business services nec & & 85.6 & 37.9 & 4.5 & 136.9 & 8.1 & 19480.9 & \\
\hline $\begin{array}{l}\text { Recreation and other } \\
\text { services }\end{array}$ & & 1.9 & 1.6 & 1.5 & 5.2 & 62.4 & 3360.2 & \\
\hline $\begin{array}{l}\text { PubAdmin Defence } \\
\text { Health Educat }\end{array}$ & & 331.4 & 112 & 312.7 & 318.8 & 22.9 & 11063.5 & \\
\hline Dwellings & & 0.6 & 0.2 & 0.6 & 0.6 & 0 & 9854.7 & \\
\hline
\end{tabular}




\section{Post-BREXIT Tariff Rates}

It is assumed that once the United Kingdom formally leaves the customs union, imports of UK goods into the European Union would face the region's MFN rates (Table A.10). Imports into the United Kingdom from Denmark and the remaining 26 EU member states would face the same MFN rates. Moreover since the effects of a UK exit are simulated before any new trade agreements are reached, it is assumed that UK exporters would face MFN treatment in all other markets post-BREXIT, and the UK would, in turn, apply the EU's MFN rates on goods from non-member countries.

The post-BREXIT MFN bilateral bound rates between the United Kingdom and non-EU member countries are applied as a mark-up on the current applied rates in the model database. The mark-up is based on the WTO information in the WITS-IDB database, and is computed to increase the applied rate in the database by the same amount as in the WITSIDB. It is calculated as one plus the percentage increase between the effectively applied tariff rate and the MFN bound rate and is computed for each sector and for each trading partner. The post-BREXIT tariff rate applied by the United Kingdom on goods imported from non EU member countries is computed as the applied rate in the database multiplied by the markup rate between the effectively applied rate and MFN bound rates of the European Union (Table A.11). If goods from a sector and trading partner enter the European Union duty free, then the new tariff rate applied is the EU's MFN bound rate for that sector and partner. The post-BREXIT tariff rate applied on UK exports by non-EU countries is computed and applied in a similar fashion. A markup rate, based on the percentage increase between the effectively applied and MFN bound rate for each UK trading partner, is applied to the tariff rate imposed on imports from the United Kingdom (Table A.12). If goods from the United Kingdom enter duty free in the pre-Brexit situation, the MFN bound rate of the region is used as the post-Brexit tariff rate. 
Table A.10. Post-Brexit ad valorem tariff rates applied to goods traded between the UK and EU (including Denmark)

\begin{tabular}{|c|c|}
\hline Sector & Tariff rate \\
\hline Agriculture & 2.25 \\
\hline Horticulture & 1.47 \\
\hline Vegetables and Fruits & 3.56 \\
\hline Other foods & 2.39 \\
\hline Other processed foods & 11.72 \\
\hline Meat products & 7.7 \\
\hline Wood products & 1.21 \\
\hline Chemical rubber plastic prods & 2.92 \\
\hline Electronic equipment & 0.74 \\
\hline Natural resources & 0.02 \\
\hline Gas & 0.7 \\
\hline Oil & 0 \\
\hline Mineral products nec & 3.59 \\
\hline Petroleum, coal products & 3.18 \\
\hline Metal products & 2.39 \\
\hline Ferrous metals & 0.49 \\
\hline Metals nec & 2.32 \\
\hline Machinery and equipment nec & 1.47 \\
\hline Manufactures nec & 1.25 \\
\hline Paper products publishing & 0.02 \\
\hline Leather products & 6.74 \\
\hline Textiles & 8.1 \\
\hline Wearing apparel & 10.9 \\
\hline Motor vehicles and parts & 5.85 \\
\hline Transport equipment nec & 2.3 \\
\hline Electricity & 0 \\
\hline Gas manufacture distribution & 0 \\
\hline
\end{tabular}

Note: 2016 EU MFN Bound import tariff rates. Simple average across partners of weighted average of EU bilateral bound rates.

Source: Author's calculation based on the WITS-IDB database. 
Table A.11. Mark-up rate applied to the current bilateral import tariff rate in order to calculate the United Kingdom's Post-Brexit tariff rate

\begin{tabular}{|c|c|c|c|c|c|c|}
\hline \multirow[b]{2}{*}{ Sectors } & \multicolumn{5}{|c|}{ Exporter } & \multirow[b]{2}{*}{ ROW } \\
\hline & CAN & $\mathrm{CHN}$ & IND & LATAM & USA & \\
\hline Agriculture & 1.00 & 1.00 & 5.00 & 2.19 & 1.00 & 2.84 \\
\hline Horticulture & 1.00 & 1.00 & 3.81 & 18.25 & 1.00 & 5.71 \\
\hline Vegetables and Fruits & 1.00 & 1.14 & 1.24 & 3.75 & 1.04 & 6.12 \\
\hline Other foods & 1.02 & 1.00 & 2.73 & 2.56 & 1.01 & 1.93 \\
\hline Other processed foods & 1.02 & 1.03 & 1.94 & 2.15 & 1.04 & 5.48 \\
\hline Meat products & 1.02 & 2.52 & 1.58 & 1.18 & 1.01 & 1.72 \\
\hline Wood products & 1.00 & 1.00 & 16.33 & 1.31 & 1.00 & 2.24 \\
\hline Natural resources & 1.00 & 1.00 & 1.00 & 1.00 & 1.00 & 1.00 \\
\hline Gas & 1.00 & 1.00 & 1.00 & 7.00 & 7.00 & 7.00 \\
\hline Oil & 1.00 & 1.00 & 1.00 & 1.00 & 1.00 & 1.00 \\
\hline Mineral products nec & 1.00 & 1.00 & 2.86 & 3.54 & 1.00 & 2.78 \\
\hline Petroleum, coal products & 1.93 & 1.76 & 1.93 & 2.61 & 1.87 & 2.27 \\
\hline Leather products & 1.01 & 1.00 & 2.08 & 1.25 & 1.01 & 2.27 \\
\hline Textiles & 1.01 & 1.00 & 1.19 & 5.64 & 1.01 & 10.55 \\
\hline Wearing apparel & 1.00 & 1.00 & 1.30 & 11.72 & 1.00 & 7.07 \\
\hline Paper products publishing & 1.00 & 1.00 & 1.00 & 1.00 & 1.00 & 7.00 \\
\hline Chemical rubber plastic prods & 1.00 & 1.00 & 1.29 & 2.11 & 1.16 & 2.66 \\
\hline Ferrous metals & 1.00 & 1.00 & 20.50 & 1.13 & 1.00 & 5.08 \\
\hline Metals nec & 1.44 & 1.04 & 1.85 & 4.10 & 1.00 & 4.62 \\
\hline Metal products & 1.00 & 1.00 & 17.44 & 2.41 & 1.00 & 2.76 \\
\hline Motor vehicles and parts & 1.00 & 1.00 & 1.09 & 7.98 & 1.00 & 4.45 \\
\hline Transport equipment nec & 1.00 & 1.00 & 1.00 & 1.00 & 1.00 & 1.51 \\
\hline Electronic equipment & 1.00 & 1.19 & 11.50 & 35.00 & 1.30 & 2.63 \\
\hline Machinery and equipment nec & 1.00 & 1.00 & 62.00 & 2.44 & 1.00 & 2.03 \\
\hline Manufactures nec & 1.00 & 1.00 & 41.00 & 6.57 & 1.00 & 2.86 \\
\hline Electricity & 1.00 & 1.00 & 1.00 & 1.00 & 1.00 & 1.00 \\
\hline Gas manufacture distribution & 1.00 & 1.00 & 1.00 & 1.00 & 1.00 & 1.00 \\
\hline
\end{tabular}

Note: Based on the 2016 tariff rates for the EU28. The markup rate one plus is the percent increase between the effectively applied rate and MFN bound rates of the European Union in each sector and for each partner. The markup rate is multiplied with the current bilateral applied rate in the model database to simulate the postBREXIT tariff rate. To calculate mark-up in WITS-IDB if the effectively applied rate is 0 , then a small applied rate is used $(0.1 \%)$ to calculate the markup.

Source: Author's calculation based on the WITS-IDB database. 
Table A.12. The mark-up multiplied by each countries ad valorem tariff rate, giving the new tariff rate $U K$ exporters could face post-UK exit

\begin{tabular}{|c|c|c|c|c|c|c|}
\hline \multirow[b]{2}{*}{ Sectors } & \multicolumn{5}{|c|}{ Importer } & \multirow[b]{2}{*}{ ROW } \\
\hline & CAN & $\mathrm{CHN}$ & IND & LATAM & USA & \\
\hline Agriculture & 2.76 & 1.01 & 7.87 & 7.98 & 5.10 & 6.79 \\
\hline Horticulture & 1.31 & 1.00 & 2.26 & 5.22 & 2.03 & 6.82 \\
\hline Vegetables and Fruits & 1.07 & 1.00 & 1.68 & 4.41 & 3.17 & 4.13 \\
\hline Other foods & 1.07 & 1.00 & 1.01 & 3.29 & 1.00 & 2.84 \\
\hline Other processed foods & 1.08 & 1.00 & 3.84 & 3.11 & 1.00 & 3.30 \\
\hline Meat products & 1.38 & 1.00 & 3.33 & 36.56 & 1.00 & 4.57 \\
\hline Wood products & 1.70 & 1.00 & 3.53 & 2.82 & 1.00 & 3.56 \\
\hline Natural resources & 6.25 & 1.03 & 5.58 & 9.57 & 1.00 & 19.15 \\
\hline Gas & 1.00 & 1.00 & 1.00 & 350.00 & 1.00 & 73.80 \\
\hline Oil & 1.00 & 1.00 & 1.00 & 194.94 & 1.00 & 3.35 \\
\hline Mineral products nec & 3.48 & 1.08 & 4.20 & 4.63 & 1.00 & 2.65 \\
\hline Petroleum, coal products & 7.57 & 1.03 & 9.23 & 10.71 & 3.18 & 10.54 \\
\hline Ferrous metals & 47.00 & 1.01 & 12.42 & 9.67 & 1.00 & 11.86 \\
\hline Metals nec & 26.70 & 2.38 & 4.57 & 13.32 & 1.00 & 5.35 \\
\hline Metal products & 3.65 & 1.04 & 3.84 & 4.55 & 1.00 & 2.67 \\
\hline Machinery and equipment nec & 6.53 & 1.07 & 4.11 & 5.24 & 1.00 & 3.80 \\
\hline Manufactures nec & 1.25 & 8.25 & 3.71 & 6.37 & 1.00 & 3.05 \\
\hline Paper products publishing & 1.00 & 1.37 & 5.77 & 6.52 & 1.00 & 5.27 \\
\hline Leather products & 1.37 & 1.53 & 2.54 & 11.86 & 1.02 & 2.27 \\
\hline Textiles & 2.04 & 1.25 & 3.90 & 3.79 & 1.00 & 4.91 \\
\hline Wearing apparel & 1.07 & 2.00 & 3.78 & 2.41 & 1.00 & 3.45 \\
\hline Chemical rubber plastic prods & 2.02 & 1.15 & 4.39 & 4.92 & 1.03 & 4.10 \\
\hline Motor vehicles and parts & 1.02 & 1.07 & 2.04 & 2.80 & 1.00 & 3.89 \\
\hline Transport equipment nec & 1.00 & 4.89 & 2.80 & 3.91 & 1.00 & 3.89 \\
\hline Electronic equipment & 1.00 & 1.00 & 1.51 & 9.77 & 1.00 & 3.96 \\
\hline Electricity & 1.00 & 1.00 & 1.00 & 1.00 & 1.00 & 1.00 \\
\hline Gas manufacture distribution & 1.00 & 1.00 & 1.00 & 350.10 & 1.00 & 4.74 \\
\hline
\end{tabular}

Note: Based on the most recently available tariff rates in the database. For Canada and the EU 2016 tariff rates are available. For China, India, and the United States 2015 tariff rates are used. For countries in Latin America and the Rest of World regions, tariff years ranged from 2011-2016. The markup rate is one plus the percent increase between the effectively applied rate applied to UK imports and MFN bound rates of the importing country. The markup rate is multiplied with the current bilateral applied rate in the model database to simulate the post-BREXIT tariff rate. To calculate mark-up in WITS-IDB if the effectively applied rate is 0 , then a small applied rate is used $(0.1 \%)$ to calculate the markup.

Source: Author's calculation based on the WITS-IDB database. 


\section{Increase cost of non-tariff measures (NTMs)}

Once the UK leaves the customs union, introduction of administrative rules like customs declaration, border checks, and health or technical compliance reviews would increase the cost of trade between the UK and the remaining EU countries. Moreover as the two regions are no longer bound to maintaining the same rules, regulatory divergence would add additional cost to exporters in not only meeting differing requirements to trade but also verifying that requirements are met. These cost would occur on both sides of the UK-EU border and would apply to both goods and services trade. Goods and services being exported from the UK would be treated as coming from any other non-EU member state. EU and Danish exporters would be required to comply to UK regulations to gain access to its market. These increase costs on both the trade of goods and services are captured by imposing non-tariff measures (NTMs) on goods and services. The increase in NTM costs is applied as an iceberg cost for the simulation.

The per cent changes in the NTMs on export from the service sector is computed as $50 \%$ of the increase in tariff equivalents of NTMs faced by the exporter once trade between the United Kingdom and EU member states is governed by MFN status (Table A.13). The tariff equivalents of services NTMs is equal to the weighted average of the CEPII import restrictiveness index across all of a country's trading partners. The NTMs faced by exporters under MFN rules, is the weighted average of the index where EU countries or the UK, depending on the exporter, is at the same level as of the rest of world.

NTMs in the goods sector is based on a new set of tariff equivalent rates estimated by the OECD (2018). Ad Valorem Equivalents based on a price-based estimated are derived for roughly 5,000 products on a bilateral basis and explicitly distinguish between several types of measures. Types of NTMs on goods trade are included in the analysis: Tariff equivalents on SPS measures, which are largely limited to the agriculture sector; and Technical Barriers to Trade (TBT) measures, which are more uniformly used across sectors with peaks in textiles, processed foods, and chemicals. Trade weighted averages of the NTM cost faced by a non-EU country when exporting into the EU are computed for the two types of NTMs at the sector level. The sum of the two types of NTMs is assumed to be the total NTM costs. The increase in non-tariff related costs, post-Brexit, of trading goods between the United Kingdom and the European Union is assumed to be $50 \%$ of sum of the two types NTMs (Table A.14). 
Table A.13. Per cent Increase in Non-Tariff Measures on Services, by product

\begin{tabular}{lrr}
\hline Service sector & GBR to EU/DNK & DNK to GBR \\
\hline Construction & 27.31 & 8.57 \\
Trade & 11.09 & 0.96 \\
Transport nec & 9.2 & 2.13 \\
Sea transport & 12.58 & 4.27 \\
Air transport & 9.2 & 2.13 \\
Communication & 23.27 & 6.09 \\
Financial services nec & 40.56 & 1.04 \\
Insurance & 4.76 & 1.49 \\
Business services nec & 13.52 & 7.36 \\
PubAdmin Defence Health Educat & 7.81 & 6.07 \\
\hline
\end{tabular}

Source: Author's calculation based on Fontagné, L., C. Mitaritonna and J. Signoret (2016), "Estimated Tariff Equivalents of Services NTMs", CEPII Working Paper, No. 2016-20, August; and Timmer, M. P., Dietzenbacher, E., Los, B., Stehrer, R. and de Vries, G. J. (2015), "An Illustrated User Guide to the World Input-Output Database: the Case of Global Automotive Production", Review of International Economics, 23: $575-605$.

Table A.14. Per cent Increase in Non-Tariff Measures on Goods between UK and EU (including Denmark)

Goods NTM shocks

\begin{tabular}{lr}
\hline Sectors & UK and EU/DNK \\
\hline Agriculture & 4.0217 \\
Vegetables and Fruits & 11.4525 \\
Horticulture & 4.4781 \\
Other foods & 5.0273 \\
Meat products & 9.3259 \\
Other processed foods & 7.3144 \\
Natural resources & 0 \\
Oil & 0 \\
Gas & 0 \\
Textiles & 4.8939 \\
Wearing apparel & 9.2508 \\
Leather products & 1.4173 \\
Wood products & 12.3953 \\
Paper products publishing & 4.4628 \\
Petroleum, coal products & 0 \\
Chemical rubber plastic prods & 4.0151 \\
Mineral products nec & 5.5467 \\
Ferrous metals & 3.727 \\
Metals nec & 1.3938 \\
Metal products & 3.572 \\
Motor vehicles and parts & 13.2476 \\
Transport equipment nec & 3.3357 \\
Electronic equipment & 2.9555 \\
Machinery and equipment nec & 3.454 \\
Manufactures nec & 2.3799 \\
\hline
\end{tabular}

Source: OECD (2018). 